\title{
High resolution integrated microbiostratigraphy of the Lower Jurassic (late Pliensbachian-early Toarcian) of central Italy
}

\author{
RAFFAELLA BUCEFALO PALLIANI \& EMANUELA MATTIOLI \\ Department of Earth Sciences, University of Perugia, O6100 Perugia, Italy
}

\begin{abstract}
The integrated use of calcareous nannofossil and dinoflagellate cyst events in a study of the late Pliensbachian -early Toarcian interval in central Italy has yielded a high resolution biostratigraphy. The use of both the first and last occurrences of selected taxa belonging to the two phytoplankton groups allows the dating of the sediments with a very refined detail, even when lithologies are unfavourable to the preservation of one fossil group. The evolutionary history of calcareous nannofossils and dinoflagellate cysts during the early Jurassic and its links with global events are responsible for the high potential of this integrated biostratigraphy. J. Micropalaeontol. 17(2): 153-172, December 1998.
\end{abstract}

\section{INTRODUCTION}

The standard biozonation for the Jurassic System is based on ammonite faunas, which possess the most important attributes for reliable biostratigraphical markers. They have restricted stratigraphical ranges, are easily identifiable, have wide geographical distributions and are generally independent of marine facies (Arkell, 1956). The considerable impetus provided by detailed worldwide geological exploration for hydrocarbon reserves (both onshore and offshore) has favoured the use of microfossils in biostratigraphy. Micropalaeontological studies have focused on Jurassic sediments, because many hydrocarbon source and reservoir rocks are of this age. Calcareous nannofossils and dinoflagellate cysts have been the object of relatively intense investigations.

Jurassic nannopalaeontology has recently received a particularly large amount of attention. Standard biostratigraphic schemes have been proposed recently for the Jurassic (Bown, 1987; Bown et al., 1988). These schemes are based mainly on the study of northern Europe, and the nannofossil events are correlated to the Boreal ammonite biostratigraphy. Some problems with the application of previous schemes to lower latitudes arise because of provincialism both of nannoplankton and ammonites. Research in the Tethyan region has proceeded at a lower pace, due mainly to the presence, at various levels, of unfavourable lithologies. Recently, a synthesis of calcareous nannofossil events in the Tethyan Realm has been attempted by Mattioli \& Erba (in press). The interval in which good biostratigraphic resolution is provided by nannofossils is the Pliensbachian-Bathonian, and in particular in the late Pliensbachian-early Bajocian, where nannofossils display a biostratigraphic potential comparable to that of the ammonites.

The first dinoflagellate cyst biozonation for the entire Jurassic

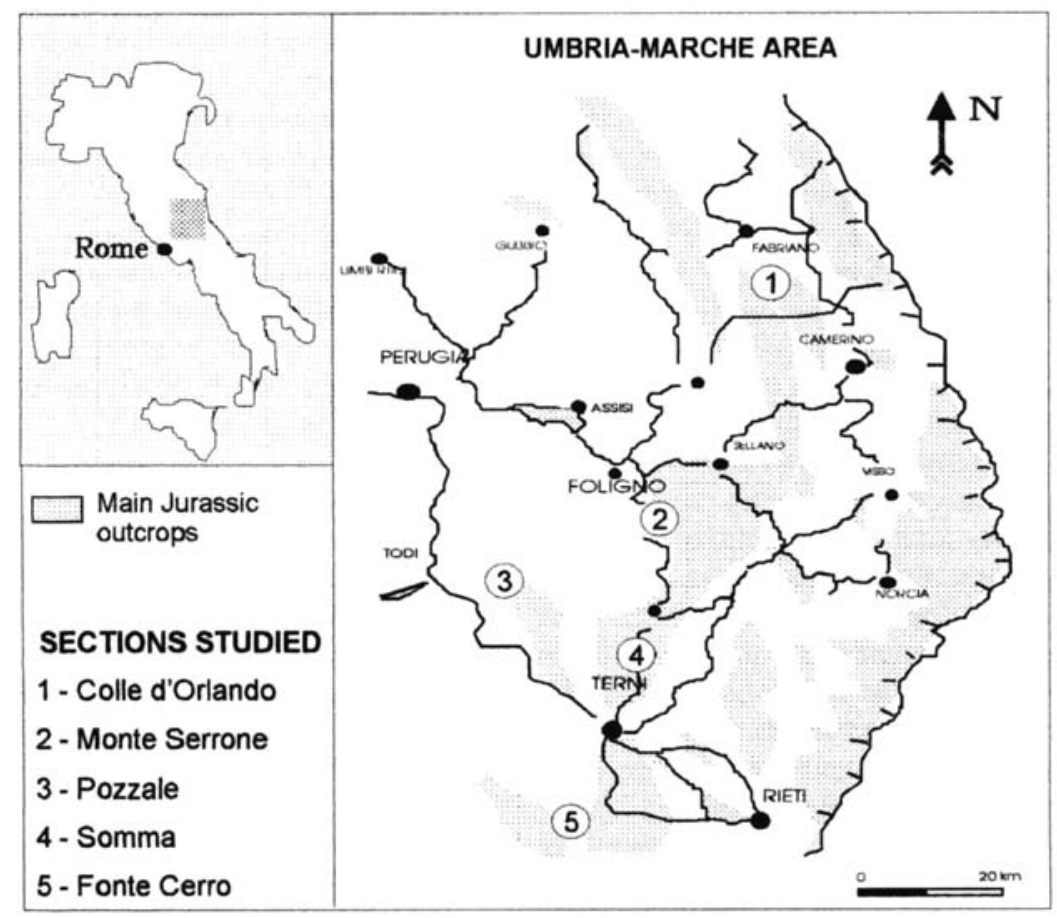

Fig. 1. Location map of the sections studied. 


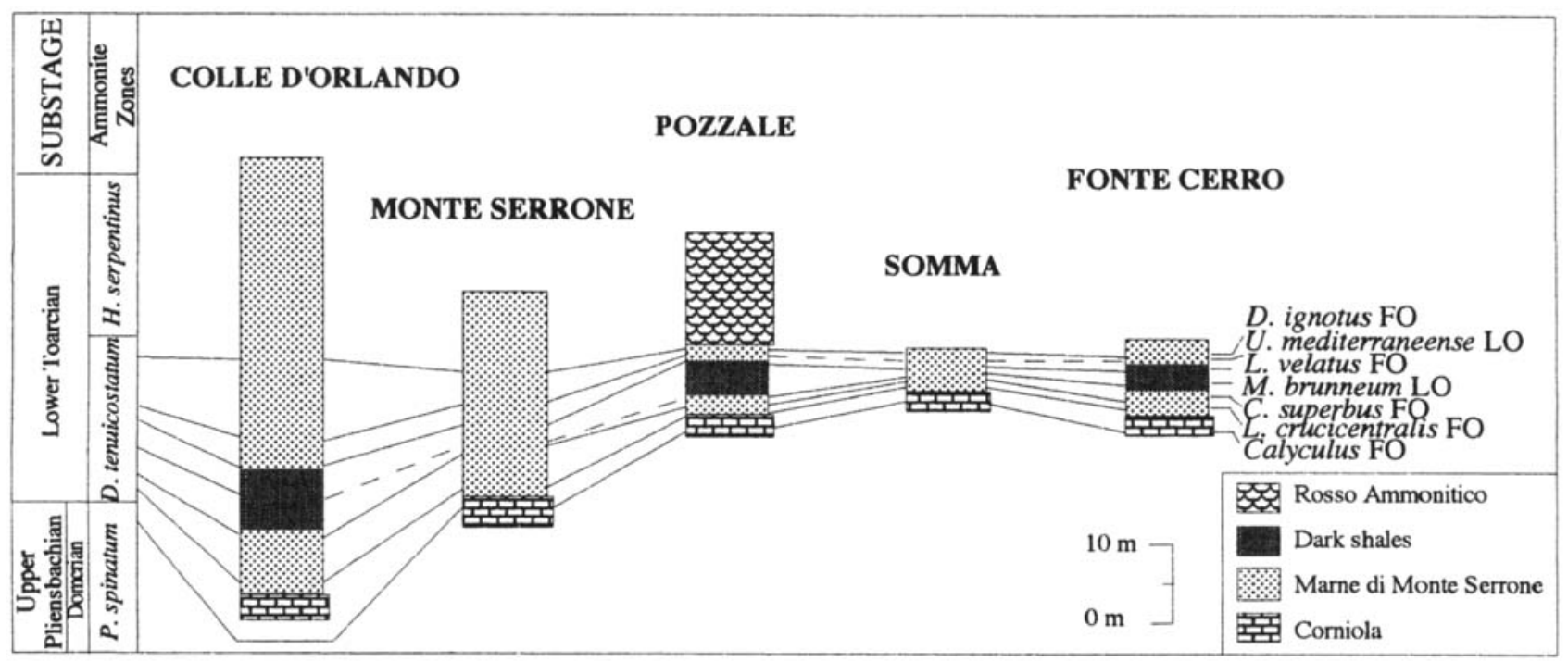

Fig. 2. Lithology and biostratigraphy of the sections studied. Correlation lines based on the most significant calcareous nannofossil and dinoflagellate cyst events are illustrated $(\mathrm{FO}=$ first occurrence; $\mathrm{LO}=$ last occurrence). Where a bioevent has not been recorded a dashed line has been used.

System was proposed by Woollam \& Riding (1983) from the study of boreholes and outcrop samples from England. In this biozonation, the boundaries of the dinoflagellate cyst zones were compared to those of the ammonites. More recently, Riding \& Thomas (1992) revised the biozonation of Woollam \& Riding (1983) including data from southern and eastern England and western Scotland. Dinoflagellate cysts exhibit lower resolution than ammonites in the Early and Mid-Jurassic, and have approximately the same biostratigraphic resolution as ammonites during the Late Jurassic.

The presence of rich and well-preserved assemblages of calcareous nannofossils and dinofiagellate cysts depends on several factors, such as lithology, palaeoenvironmental conditions and diagenetic overprint. Organic matter is preferentially concentrated in fine grained sediments deposited under dysaerobic-anoxic conditions (Tyson, 1987). It is lacking in coarse grained and calcareous sediments which were deposited in highly oxidizing regimes in which the organic constituents are rapidly degraded. Calcareous nannofossil preservation is strongly dependent on the lysocline depth in the seas, burial conditions, and the presence and diagenesis of organic matter. Well preserved assemblages are generally observed in marly lithotypes rather than in argillaceous and calcareous ones, where postburial conditions often severely alter the assemblage composition (Mattioli, 1995). Frequently, the two phytoplankton fossil groups show their highest concentration and better preservation in different lithologies: calcareous nannofossils area common in limestones and marly limestones, while dinoflagellate cysts are more abundant in bituminous marls and shales.

Ecological conditions, such as trophic resources, may profoundly affect the composition of phytoplankton assemblages. According to Hallock (1987) coccolithophorids may grow in low concentrations of nutrients, whereas dinoflagellates generally dominate in mesotrophic conditions. The different ecology and lithological preferences for their preservation suggest that their integration may provide a detailed biostratigraphical framework, independent of sedimentary facies.

Umbria-Marche (central Italy) is an important biostratigraphic reference area for the Tethyan Realm, because of the continuity of numerous successions and the rich micro- and macrofossil content. Moreover, it represents a key region in which to understand the evolution of the western Tethys during the Jurassic. Due to the presence of several sections which are well dated by ammonites, Umbria-Marche is particularly suitable for carrying out integrated biostratigraphy based on calcareous nannofossils and dinoflagellate cysts. This study focuses on the late Pliensbachian-early Toarcian, an interval characterized by numerous global palaeoecological and palaeogeographical events (i.e. speciations, transgression and anoxia).

The aims of this paper are:

- the description of calcareous nannofossil and dinoflagellate cyst distributions in the Early Jurassic of central Italy;

- the identification of the most significant bioevents in the two phytoplankton groups;

- a bioevent integration in order to obtain a high resolution biostratigraphic scheme.

\section{GEOLOGICAL SETTING}

The Umbria-Marche area is located in the southerly part of the Northern Apennines, delimited by the Sillaro Valley to the north and the Latium-Abruzzi carbonate platform to the south (Fig. 1). The Jurassic successions were deposited in a basin which originated during a phase of extensional tectonics, related to the opening of the western Tethys and inducing the breakup and drowning of the Calcare Massiccio carbonate platform (Colacicchi et al., 1989; Cresta et al., 1989). The palaeotopography was quite complex as a consequence of rifting and subsequent differential subsidence: structural highs were connected by more or less steep slopes to the troughs. This palaeogeographical framework is reflected in the different depositional patterns 


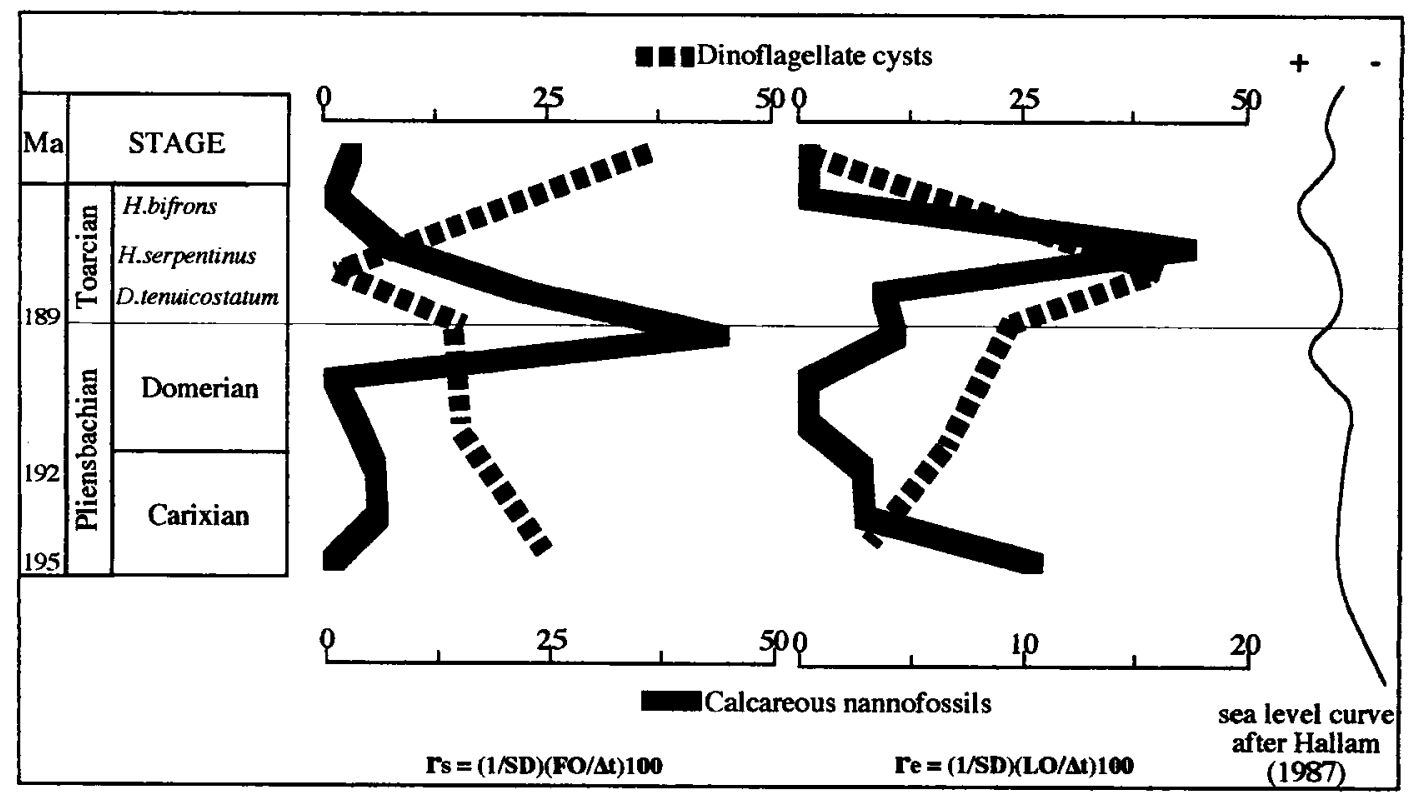

Fig. 3. Evolutionary rates of the calcareous nannofossils and dinoflagellate cysts related to the eustatic curve of Hallam (1987). The speciation and extintion rates have been calculated according to Roth (1986). The time scale used is from Gradstein et al. (1994). The number of phytoplankton species has been obtained from integration of the published data with the present ones.

which occurred. On the structural highs, condensed sequences can be recognized, whereas in the deepest depressions thick and continuous sequences with several resedimented levels were deposited. The most common situation is represented by continuous sequences with intermediate thicknesses and without frequent resedimented levels. The subsidence and relative sealevel reached their maximum during the Toarcian, when argillaceous lithotypes were deposited throughout the basin. Anoxic conditions developed in most of the western Tethys at that time, probably as consequence of the sea level rise (Hallam, 1987; Jenkyns, 1985).

\section{MATERIAL AND METHODS}

Five successions were sampled in the Umbria-Marche area, in order to document all the different sectors of the basin, following a transect from the areas close to the Latium-Abruzzi carbonate platform and influenced by its evolution to the most distal areas (Fig. 2).

The Colle d'Orlando section is located in the northeastern area of the Umbria-Marche Basin (Fig. 1). The examined interval is early Toarcian in age, between two horizons containing several specimens of Dactylioceras spp. In central Umbria, the Monte Serrone and Somma sections have been investigated. The interval studied in the Monte Serrone section comprises the late Domerian, $P$. spinatum Zone, the early Toarcian D. tenuicostatum Zone and $H$. serpentinus Zone (Reale et al., 1992). In the Somma section, because of the lack of ammonites, the biostratigraphy is based on calcareous nannofossils and dinoflagellate cysts. The Pozzale section is in central western Umbria and it is dated as late Domerian-early Toarcian, according to the ammonite faunas (Mattioli, 1995; Nini et al., 1995). The Fonte Cerro section is located in the Monti Sabini area (north Latium). Some ammonite horizons give an age of $D$. tenuicostatum to $H$. serpentinus Zones for the studied interval (Bucefalo Palliani \& Mattioli, 1994).

The lithotypes studied comprise: (1) the uppermost levels of the Corniola Unit, nutty to white micritic limestones with occasional detrital levels interbedded in some cases with chert in layers or nodules, Domerian in age; (2) the Marne di Monte Serrone Formation (Pialli, 1969), marls and argillaceous marls yellow to dark in colour, with occasional calcarenites, which may include black shale levels, early Toarcian in age; (3) the basal portion of the Rosso Ammonitico Unit, nodular marls and limestones, red to greenish, in which the clay content decreases upwards, early to mid-Toarcian in age.

Samples were generally taken at regular intervals, from more micritic limestones and/or from marlstones, trying to avoid the detrital levels. Sample spacing varied from 5 to $20 \mathrm{~cm}$. Quantitative studies on calcareous nannofossil and dinoflagellate cyst assemblages have been performed on the same samples. Samples for observations of calcareous nannofossils under a light microscope were prepared with standard techniques, described by Mattioli (1995). Palynological slides were obtained by standard preparation procedures, involving acid treatment, oxidative maceration and sieving using a $10 \mu \mathrm{m}$ mesh (Wood et al., 1996).

\section{CALCAREOUS NANNOFOSSIL ASSEMBLAGES}

A total of 313 samples were quantitatively studied. Calcareous nannofossil preservation varies from poor to moderate depending on the different lithotypes. The poorest preservation was observed in the Colle d'Orlando and Fonte Cerro sections and, concomitantly with (a) detrital limestones, in which the high primary porosity allowed the aggressive diagenetic waters to circulate, and (b) in the argillaceous layers in which the highest values of Total Organic Carbon (TOC) have been recorded, in relation to the diagenesis of the organic matter. The predominant lithotypes are represented by marly limestones, ensuring a 

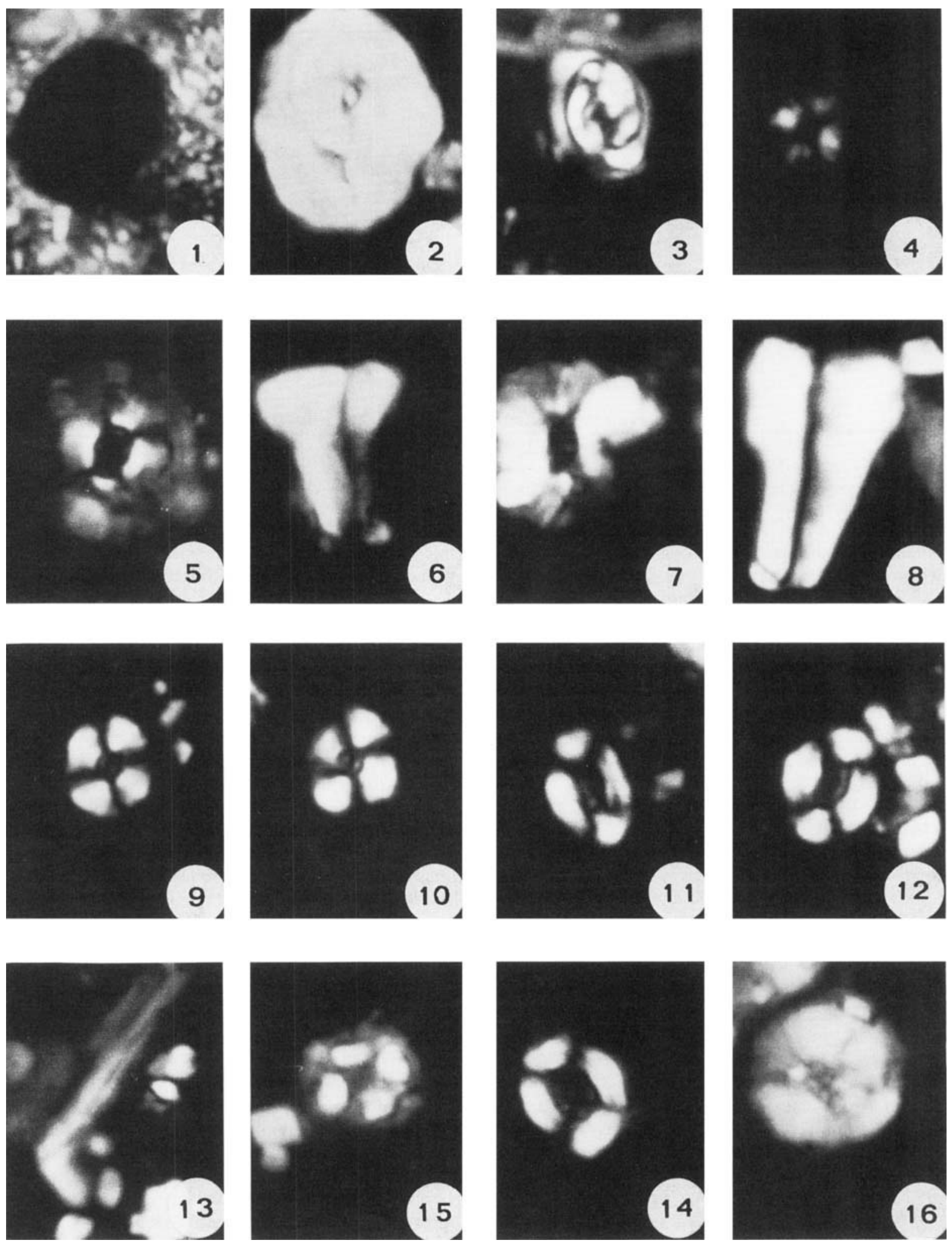


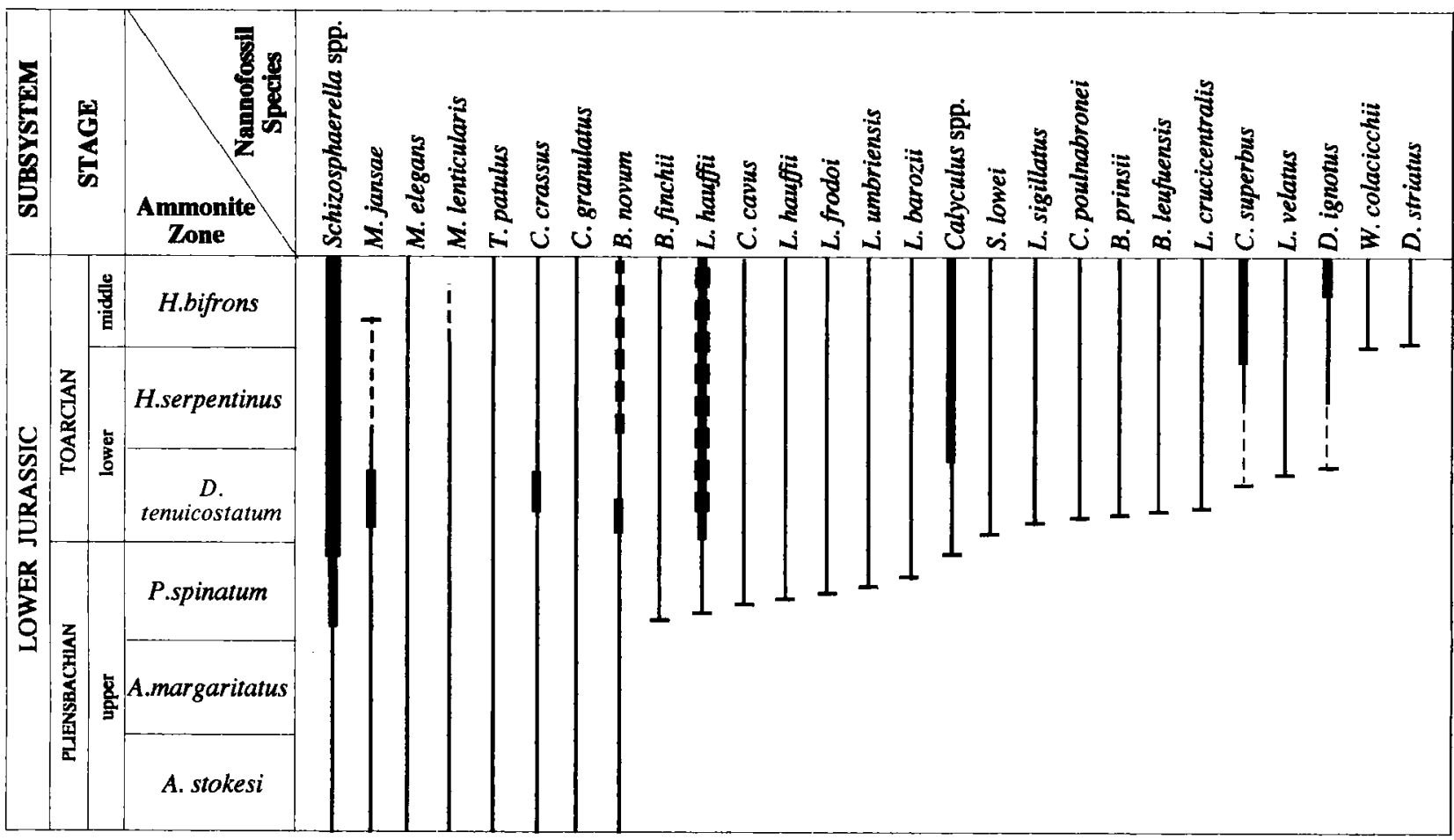

Fig. 4. Stratigraphical distribution of calcareous nannofossils from the Lower Jurassic of central Italy. The line thickness is related to the relative abundances of each species in the assemblages. Dashed lines indicate discontinuous occurrences.

moderately good nannofossil preservation, and the sample density is high. The effects of diagenetic impoverishment can be considered negligible for the following biostratigraphic considerations.

All the sections studied display comparable nannofossil abundance and preservation, although the Pozzale and Monte Serrone successions seem to be the richest (Appendix B, Figs B1-B6). The data presented in this paper are supported by the dataset collected in several other successions studied in central Italy (Mattioli, 1995).

A significant change was observed across the DomerianToarcian boundary in the assemblage composition of calcareous nannofossils, as at that time the diversification rate is the highest of the entire Jurassic System (Bown, 1996) and the speciations largely dominate over the extinctions (Fig. 3). The range charts of all the sections studied are illustrated in Appendix B (Figs B1-B6). The biostratigraphical data are summarized in Fig. 4.

In the latest Domerian (top of the $P$. spinatum Zone) the assemblages are low in diversity and never abundant. The prominent taxa in the assemblages are represented by the incertae sedis Schizosphaerella spp., Mitrolithus jansae, Crepidolithus crassus, rare specimens of the genus Biscutum (i.e. B. dubium) and genus Lotharingius (such as $L$. hauffii and $L$. barozii). After a long period of evolutionary quiescence which lasted the entire Pliensbachian, several new genera and species first appeared. Among these, some had a successful evolutionary history, being long ranging species. The first appearances of Crepidolithus cavus ( $=C$. impontus of some authors), Biscutum finchii and Biscutum grande are significant. These species have a distribution restricted to the Tethyan Realm (Bown, 1987; Mattioli \& Erba, in press). A great diversification in the Family Watznaueriaceae is observed in this interval as many different species appeared, such as Lotharingius hauffi, $L$. barozii and $L$. sigillatus. Lotharingius umbriensis and $L$. frodoi have been recently described by Mattioli (1996) from the Lower Toarcian of western Tethys. The first occurrences of $L$.hauffii and $L$.

\section{Explanation of Plate 1}

All light micrographs, crossed nicols, approximately $\times 4600$. fig. 1. Schizosphaerella sp. indet. Deflandre \& Dangeard, 1938. Sample PO 7.20, Pozzale section. fig. 2. Crepidolithus crassus (Deflandre, 1954) Noël, 1965. Sample PO 7.20, Pozzale section. fig. 3. Tubirhabdus patulus Rood et al., 1973. Sample MS1 19.20, Monte Serrone section. fig. 4. Biscutum dubium (Noël, 1965) Grün in Grün et al., 1974. Sample PO 7.20, Pozzale section. fig. 5. Biscutum grande Bown, 1987. Sample PO 7.20, Pozzale section. fig. 6. Calyculus sp. indet.. Sample MS1 19.20, Monte Serrone section. fig. 7. Calyculus sp. indet.. Sample MS1 19.20, Monte Serrone section. fig. 8. Carinolithus poulnabronei Mattioli, 1996. Sample MS1 19.20, Monte Serrone section. fig. 9. Lotharingius hauffii Grün \& Zweili in Grün et al., 1974. Sample MS1 19.20, Monte Serrone section. fig. 10. Lotharingius frodoi Mattioli, 1996. Sample MS1 19.20, Monte Serrone section. fig. 11. Bussonius prinsii (Noël, 1973) Goy, 1979. Sample MS1 19.20, Monte Serrone section. fig. 12. Lotharingius crucicentralis (Medd, 1971) Grün \& Zweili, 1980. MS1 19.20, Monte Serrone section. fig. 13. Carinolithus superbus (Deflandre, 1954) Prins in Grün et al., 1974. Sample MS1 19.20, Monte Serrone section. fig. 14. Lotharingius velatus Bown \& Cooper, 1989. Sample MS1 19.20, Monte Serrone section. fig. 15. Discorhabdus ignotus (Gorka, 1957) Perch-Nielsen, 1968. Sample PO 7.20, Pozzale section. fig. 16. Discorhabdus striatus Moshkovitz \& Ehrlich, 1976. Sample PO 7.20, Pozzale section. 


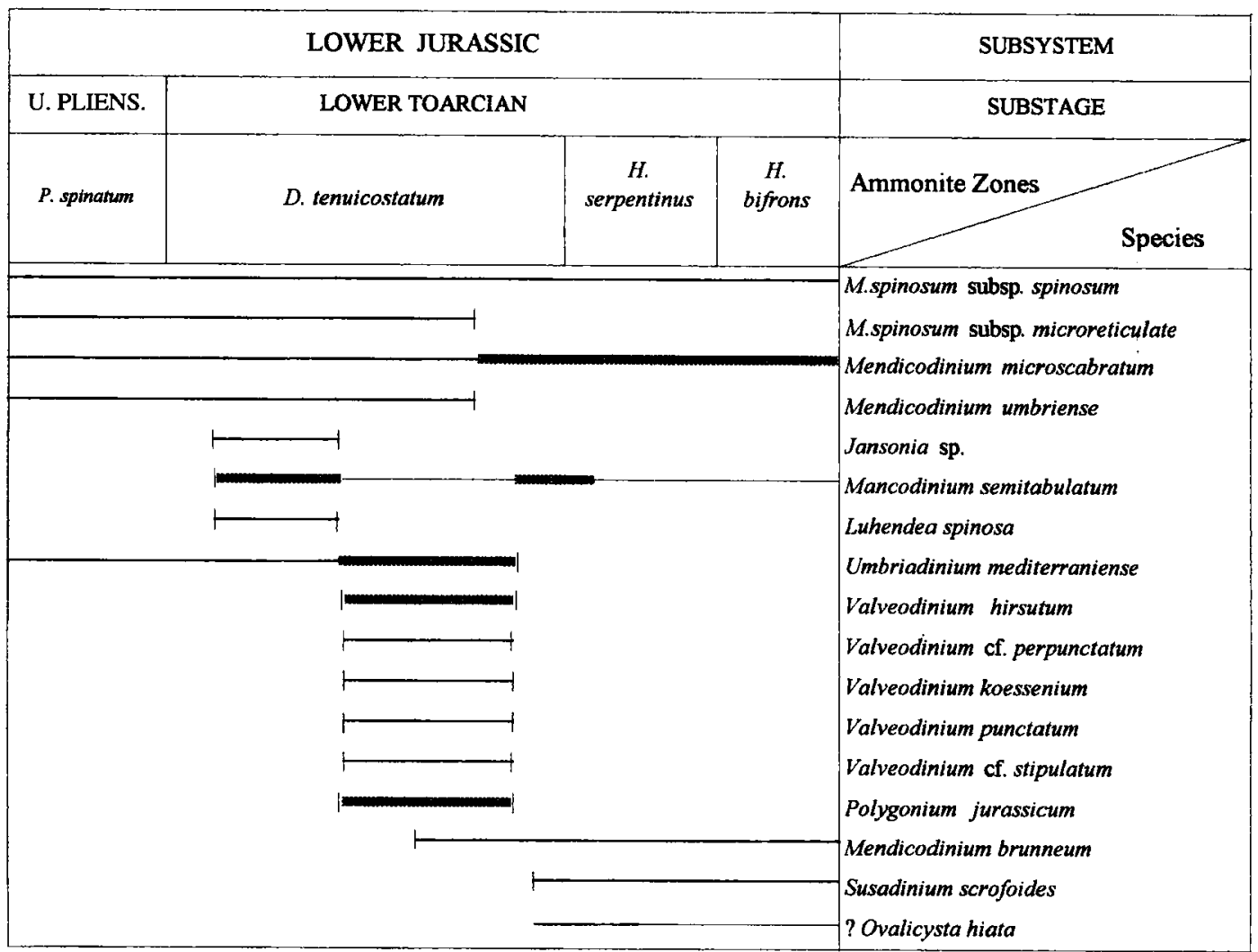

Fig. 5. Stratigraphical distribution of dinoflagellate cysts from the Lower Jurassic of central Italy. The line thickness is related to the relative abundances of each species in the assemblages.

sigillatus seem to be two reliable events recorded concordantly in both the Tethyan and Boreal domains. The entry of the Family Calyculaceae with the genus Calyculus is also observed. This event constitutes a significant marker for the PliensbachianToarcian boundary in the Tethyan Realm.

This diversification trend continued into the early Toarcian $D$. tenuicostatum Zone, in which the genus Carinolithus appeared with $C$. poulnabronei and $C$. superbus, which are however rare immediately after their appearance, becoming common in the mid-Toarcian. Among the Watznaueriaceae, rare specimens of Bussonius prinsii and B. leufuensis, Lotharingius crucicentralis and $L$. velatus first appear, which, although rare, are typical constituents of Toarcian assemblages. In the uppermost part of this zone the easily recognizable Discorhabdus ignotus has its first appearance. Also D.ignotus is very rare after its appearance but becomes abundant in the mid-Toarcian, probably due to favourable palaeoenvironmental conditions. In the early Toarcian $H$. serpentinus Zone, the important genus Watznaueria, which dominates Mid and Late Jurassic assemblages, appears with $W$. colacicchii and Watznaueria sp. 1. The significant taxon Mitrolithus jansae, which dominated the early Jurassic assemblages, abruptly decreases in abundance in advance of its disappearance.

The assemblages are not rich in the Domerian and lowermost part of the Toarcian, both in species diversity and total abundance. In the early $D$. tenuicostatum Zone, a notable increase of species diversity and total abundance occurred. Although many variations are distinguished in the assemblage composition, and in the late $D$. tenuicostatum Zone the nannoplankton experienced a crisis, the early Toarcian is

Explanation of Plate 2

All photomicrographs taken in plain transmitted light, magnification $\times 1250$. fig. 1. Valvaeodinium hirsutum Bucefalo Palliani \& Riding, 1997. Sample CO 14.80 (2), England Finder coordinate Q 36, Colle d'Orlando section. fig. 2. Valvaeodinium hirsutum Bucefalo Palliani \& Riding, 1997. Sample CO 8.50, England Finder coordinate G 42-1/3, Colle d'Orlando section. fig. 3. Umbriadinium mediterraneense Bucefalo Palliani \& Riding, 1997. Sample FCl 0.70 (6), England Finder coordinate Q 47-4, Fonte Cerro section. fig. 4. Umbriadinizm mediterraneense Bucefalo Palliani \& Riding, 1997. Sample FCl 0.70 (6), England Finder coordinate L 35, Fonte Cerro section. fig. 5. Umbriadinium mediterraneense Bucefalo Palliani \& Riding, 1997. Sample CO 8.50, England Finder coordinate S 37, Colle d'Orlando section. fig. 6. Umbriadinium mediterraneense Bucefalo Palliani \& Riding, 1997. Sample PO 3.60 (2), England Finder coordinate L 38, Pozzale section. fig. 7. Polygonium jurassicum Bucefalo Palliani et al., 1996. Sample FC1 1.00 (1), England Finder coordinate K 28, Fonte Cerro section. fig. 8. Mendicodinium spinosum subsp. perforatum Bucefalo Palliani et al., 1997. Sample PO 3.60 (4), England Finder coordinate H 24-3, Pozzale section. fig. 9. Mendicodinium microscabratum Bucefalo Palliani $e t$ al., 1997. Sample CO 6.90, England Finder coordinate R 36, Colle d'Orlando section. fig. 10. Mendicodinium brunneum Bucefalo Palliani et al., 1997. Sample CO 13.10 (1), England Finder coordinate D 31-3, Colle d'Orlando section. fig. 11. Jansonia sp. Sample CO 7.30 (1), England Finder coordinate W 34, Colle d'Orlando section. fig. 12. Jansonia sp. Sample CO 6.90 (2), England Finder coordinate O 39-3, Colle d'Orlando section. 

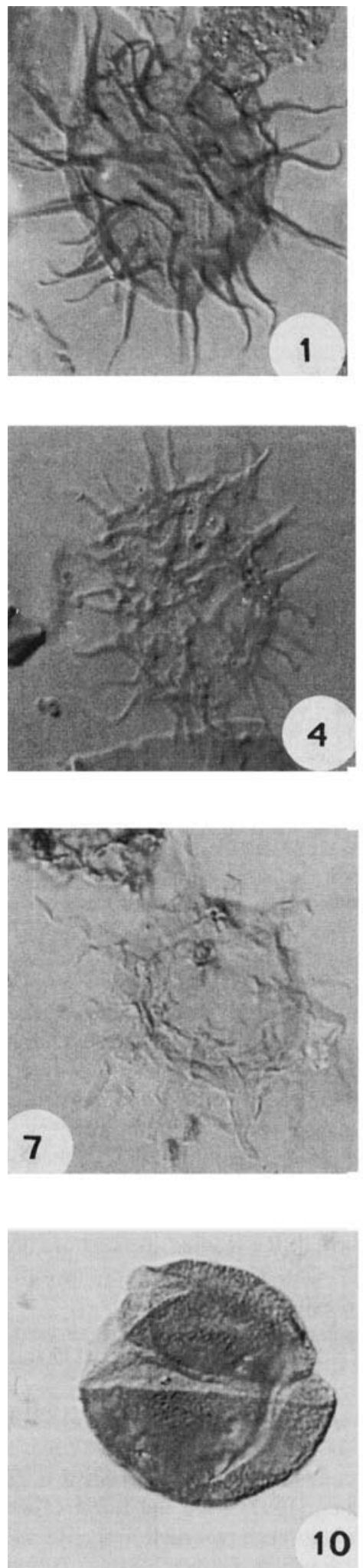
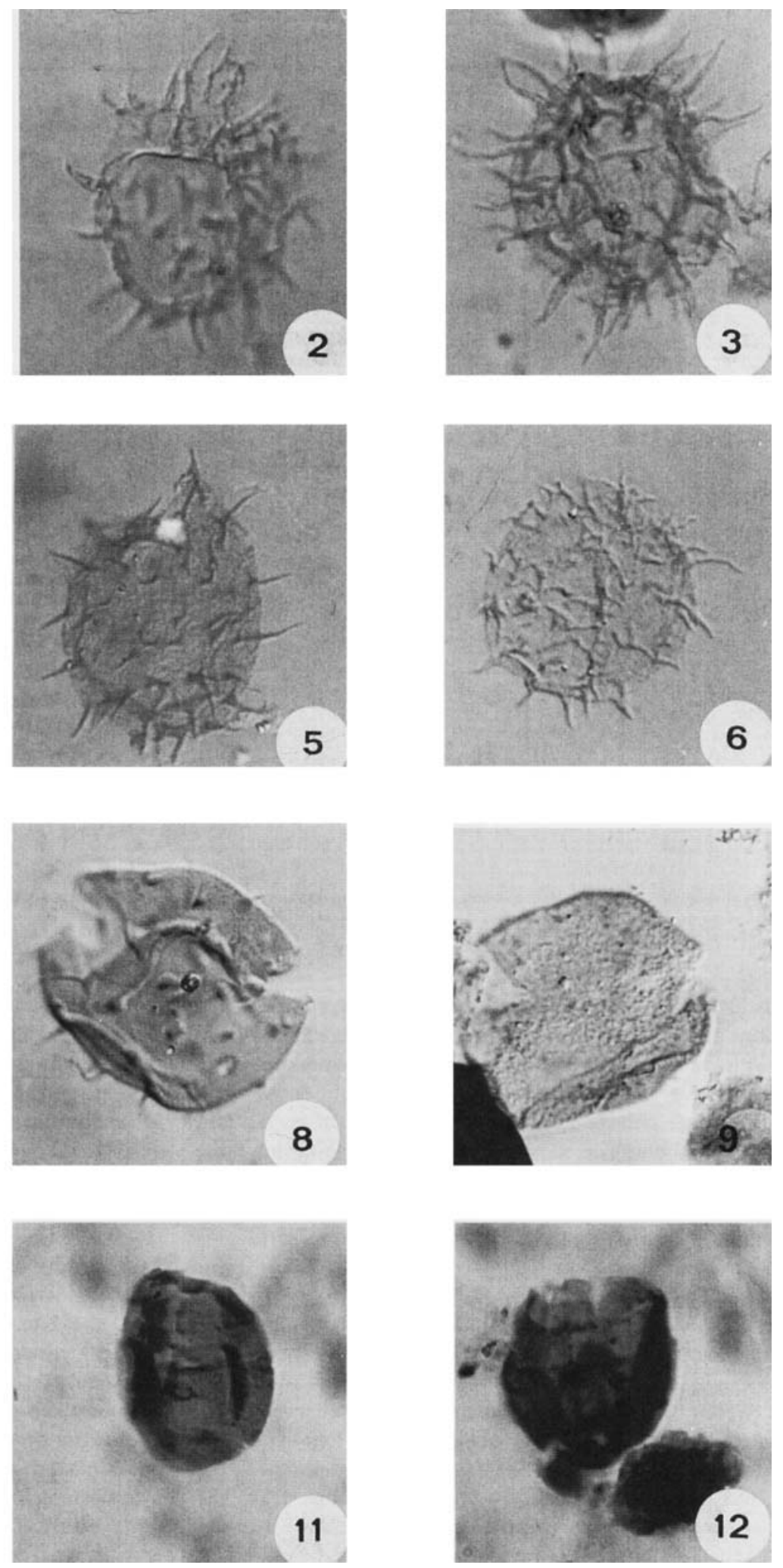


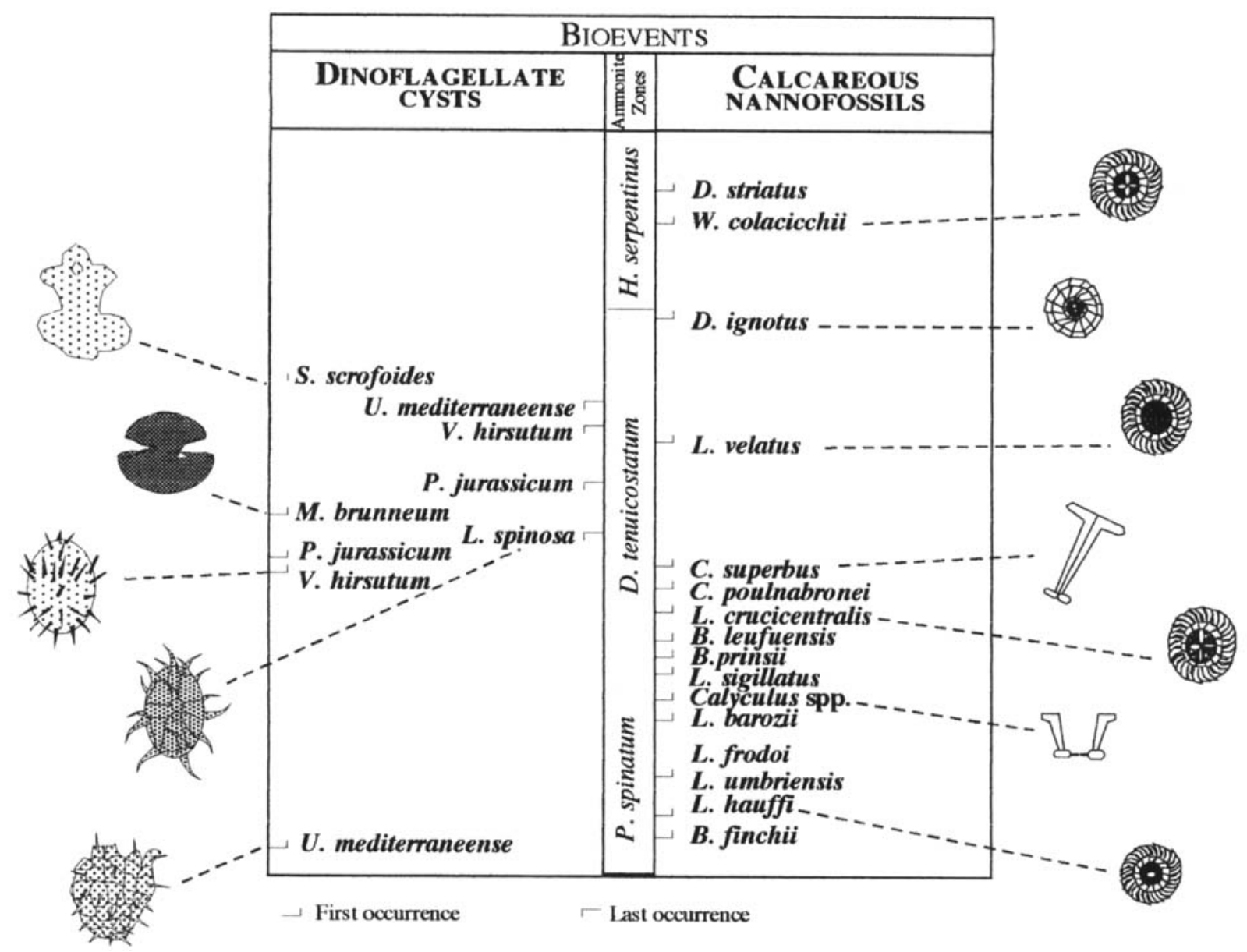

Fig. 6. Integrated phytoplanktonic events, both first and last occurrences, with regards to the ammonite zones during the late Pliensbachian-early Toarcian.

generally an interval in which great abundances and a diversified assemblage are observed in the areas studied. Large fluctuations in the abundance of each taxon, depending on palaeoecological conditions, were observed by Bucefalo Palliani \& Mattioli (1995). Although palaeoeology and preservation often induced fluctuations of abundance, a certain continuity is observed in the occurrences of various species. The continuity in the findings is also a consequence of the close spaced sampling, which allowed the recognition of the original distribution of nannofossils.

\section{DINOFLAGELLATE CYST ASSEMBLAGES}

Forty samples were studied for palynomorphs. In central Italy the Pliensbachian lithologies comprise calcareous lithotypes and are not favourable to palynological analyses. The rare marly intercalations generally are palynologically barren. The only information regarding the late Pliensbachian $(P$. spinatum Zone) is from the Fonte Cerro section (Appendix C, Fig. C5). The lower Toarcian lithologies (Marne di Monte Serrone Formation) are promising for palynological investigations. Their organic content and the variations of the terrestrial and marine organic constituents are high and related to eustatic fluctuations (Bucefalo Palliani \& Cirilli, 1993; Bucefalo Palliani et al., in press). The most abundant and diverse dinoflagellate cyst assemblages have been recorded in the sections characterized by bituminous lithologies within the Marne di Monte Serrone Formation (i.e. Colle d'Orlando, Pozzale and Fonte Cerro). In other sections, the dinoflagellate cyst data are rare (i.e. Somma and Monte Serrone). However, the integration of the data from all the sections studied, allows the elucidation of the dinoflagellate cyst distribution in the Lower Toarcian of central Italy. The range charts of all the studied sections are illustrated in Appendix C (Figs C1-C5). The biostratigraphical data have been summarized and illustrated in Fig. 5 .

In the late Pliensbachian (Domerian) and early Toarcian (early D. tenuicostatum zone) the dinoflagellate cyst assemblages are characterized by rare specimens of Mendicodinium ( $M$. spinosum subsp. spinosum, $M$. spinosum subsp. perforatum, $M$. microscabratum and $M$. umbriense) and by Umbriadinium mediterraneense. The Mendicodinium species were first described by Bucefalo Palliani et al. (1997) from the Lower Toarcian of central Italy. They have also been recorded in the Pliensbachian and Lower Toarcian of southern France, Greece, Hungary and Portugal (Baldanza et al., 1995; Bucefalo Palliani, 1996; Bucefalo Palliani \& Riding, 1998). According to Bucefalo Palliani (1996) the base of the Pliensbachian in the Tethyan 
domain is marked by the first occurrence of the 'Mendicodinium group', consisting of small cysts with varying wall ornamentation. The several species of Mendicodinium are rarely present throughout the Lower Toarcian ( $D$. tenuicostatum Zone). Mendicodinium microscabratum has been recorded up to the late Toarcian in southern France (Bucefalo Palliani \& Riding, 1998). Umbriadinium mediterraneense is a suessiacean dinoflagellate cyst described by Bucefalo Palliani \& Riding (1997a) from northwest Greece, central Italy and Hungary. In central Italy its stratigraphical range is from late Pliensbachian $(P$. spinatum Zone) to early Toarcian ( $D$. tenuicostatum Zone). It is rare in the late Pliensbachian and lower part of the $D$. tenuicostatum Zone and becomes abundant in the middle-upper part of the $D$. tenuicostatum Zone. The range top of $U$. mediterraneense in central Italy is at the top of the $D$. tenuicostatum Zone.

Mancodinium semitabulatum has been recorded from the entire $D$. tenuicostatum Zone. It is a long ranging (Pliensbachian-Bajocian) and cosmopolitan taxon, first described from the Upper Pliensbachian of Germany (Morgenroth, 1970). In central Italy, $M$. semitabulatum exhibits a decrease in abundance in the middle portion of the $D$. tenuicostatum Zone, within the most bituminous lithotypes. This trend has been interpreted as the result of the dinoflagellate life strategies and the stable palaeoecological conditions of the palaeoenvironment (Bucefalo Palliani, 1996). Rare specimens of Luehndea spinosa have been recorded in the Fonte Cerro and Pozzale sections (Appendix C, Figs C3 \& C5) in the lower part of the D. tenuicostatum Zone. The range of $L$. spinosa is restricted to the late Pliensbachianearliest Toarcian (Riding, 1987) in northern Europe. In the lower portion of the $D$. tenuicostatum Zone of the Colle d'Orlando section, rare specimens of Jansonia sp. have been reported. Jansonia sp. exhibits the same wall ornamentation of the Bathonian Jansonia manifesta but with lower parasutural ridges. The parasutural ornamentation of Jansonia sp. is similar to that of Jansonia jurassica. The low number of specimens recorded prevents a detailed and formal description of this species.

In the middle part of the $D$. tenuicostatum Zone the dinoflagellate cyst assemblages from central Italy record the highest species diversity (Fig. 5). The assemblages are characterized by several species of Valvaeodinium, such as V. hirsutum, $V$. koessenium, Valvaeodinium cf. perpunctatum, $V$. punctatum and $V$. stipulatum. Valvaeodinium punctatum, $V$. perpunctatum and $V$. stipulatum were first described as Comparodinium from the late Pliensbachian-early Toarcian of southwest Germany (Wille \& Gocht, 1979). Valvaeodinium koessenium was recorded by Morbey (1975) from the Rhaetian of Austria. In the Pliensbachian and Lower Toarcian, Wille \& Gocht (1979) recognized Comparodinium cf. koessenium, characterized by the lack of superficial microreticulation. Valvaeodinium hirsutum was described by Bucefalo Palliani \& Riding (1997a) from the Lower Toarcian of Greece and central Italy.

In the middle portion of the $D$. tenuicostatum Zone, abundant specimens of the acritarch Polygonium jurassicum Bucefalo Palliani et al. 1996 and the first occurrence of Mendicodinium brunneum have also been recorded. This species of Mendicodinium has been reported in the Lower Toarcian (D. tenuicostatum Zone) of Greece, the Lower Toarcian (D. tenuicostatum Zone and $H$. serpentinus Zone) of Portugal and the Upper Toarcian (Grammoceras thouarsense Zone) of southern France (Bucefalo Palliani, 1996; Bucefalo Palliani \& Riding, 1998).

In the upper part of the D. tenuicostatum Zone, Susadinium scrofoides and Ovalicysta? hiata, taxa belonging to the Parvocysta suite of Riding (1984), first occurred. These bioevents have been recognized by Bucefalo Palliani \& Riding (1997b) and Bucefalo Palliani \& Mattioli (1994). The discrepancies regarding the first occurrence of the Parvocysta suite in the Tethyan and Boreal domains have been explained through a mid-Toarcian migrational event, related to the gradual oxygenation of the Boreal seas following the early Toarcian anoxic event (Bucefalo Palliani \& Riding, in press ).

The palynological data from the $H$. serpentinus Zone reveal low diversity dinoflagellate cyst assemblages, consisting of $M$. semitabulatum, $M$. microscabratum, $M$. brunneum and representatives of the Parvocysta suite.

\section{INTEGRATED BIOSTRATIGRAPHY}

The large number of phytoplankton events recorded in the late Pliensbachian and early Toarcian makes possible the selection of a certain number of first and last occurrences (FO and LO, respectively) of species which are useful for biostratigraphical correlation. Only species with a well defined stratigraphical range have been considered. The occurrences of these species are calibrated with ammonites and recorded in central Italy as in other Tethyan and sometimes Boreal domains. Where possible, the taxa which are more resistant to diagenetic processes have been chosen. In some cases more delicate taxa have been considered, such as the calcareous nannofossil $D$. ignotus and the dinoflagellate cyst $U$. mediterraneense, because of their stratigraphical importance and easily recognizable morphological characteristics. Due to a careful taxonomic revision and the introduction of a new genus and some new species, all the species exhibit a stable and well defined taxonomy (Bucefalo Palliani et al., 1996, Bucefalo Palliani \& Riding, 1997a; Mattioli, 1996). The selected species display characteristic and easily recognizable features under the light microscope, and are widespread and commonly found throughout the Tethyan domain.

From the integrated scheme of Fig. 6, an interplay between the two fossil groups is evident. A more detailed biostratigraphical resolution for the Pliensbachian-Toarcian boundary is provided by calcareous nannofossils, whereas the dinoflagellate cysts yield greater detail in the uppermost part of the $D$. tenuicostatum Zone.The nannofossil resolution is again high between the $D$. tenuicostatum and $H$. serpentinus zones. The great detail provided by phytoplankton in this time interval is linked to their evolutionary history, characterized by speciation events and by different diversification and turnover trends. The high potential of the calcareous nannofossil and dinoflagellate cyst integration lies in the slight diachroneity of the speciation and turnover events recorded by the two phytoplanktonic groups (Fig. 3). The notable speciation event experienced by calcareous nannofossils at the transition between the Pliensbachian and Toarcian is concomitant with the inception of the early Toarcian transgression, which increased the number of available niches. The dinoflagellate cyst record indicates high 
turnover, concomitant with the stressed palaeoenvironmental conditions during the early Toarcian anoxic event (Fig. 3). The low oxygen content at the sea bottom diminished the number of available niches for the cyst-producing dinoflagellates.

The first event recorded in the late Pliensbachian $(P$. spinatum Zone) is the FO of $U$. mediterraneense. An older occurrence of this taxon is not excluded, because the poor preservational potential of the late Pliensbachian lithologies prevents the collection of detailed palynological data. The PliensbachianToarcian boundary is marked by a succession of 12 nannofossil events (Fig. 6). Several species of Lotharingius appear, suggesting an acme in the evolutionary history of this genus. Among these events the FOs of $L$. hauffii ( $P$. spinatum Zone) and $L$. crucicentralis (D. tenuicostatum Zone) are significant, because of their good recovery in several different areas. The Pliensbachian-Toarcian boundary is also defined by the entry of the Genus Calyculus. This event has always been referred to as Late Domerian in the Tethyan Realm (for a revision, see Mattioli \& Erba, in press), although in North Europe it is reported in the early Domerian (Crux, 1984) or as sporadic from the MidCarixian and continuous from the Late Domerian (Bown, 1987; Bown et al., 1988). In the basal Toarcian two species of the genus Bussonius first appeared. As these specimens are delicate, an older occurrence in the late Pliensbachian limestones of the Corniola Unit is not excluded. Another important genus appearing within the D. tenuicostatum Zone is Carinolithus, with the two subsequent easily recognizable species $C$. poulnabronei and $C$. superbus. Between the FOs of $C$. superbus and $L$. velatus, several dinoflagellate cysts occur. The $\mathrm{FO}$ of $V$. hirsutum is synchronous with the FO of $C$. superbus which is followed by the FO of the acritarch $P$. jurassicum and by the LO of $L$. spinosa. Polygonium jurassicum has a very restricted range and it disappears within the $D$. tenuicostatum Zone. The LO of $L$. spinosa, a well calibrated and recognizable event both in the Boreal and Tethyan realms, is followed by the FO of $M$. brunneum. Above the FO of $L$. velatus, the subsequent LO of $V$. hirsutum and $U$. mediterraneense is verified. The last dinoflagellate event in the $D$. tenuicostatum Zone is the FO of $S$. scrofoides, which represents the first species of the Heterocapsaceae lineage. The end of the $D$. tenuicostatum Zone corresponds to the entry of the genus Discorhabdus with the species $D$. ignotus. No dinoflagellate events are recorded in the $H$. serpentinus Zone and this may reflect a period of relative evolutionary quiescence. Nannoplankton diversification increased again in the late $H$. serpentinus Zone, with the FO of D. striatus and the entry of the important genus Watznaueria, which dominates all later Jurassic assemblages.

\section{DISCUSSION AND CONCLUSIONS}

Integration of selected calcareous nannofossil and dinoflagellate cyst events has produced a detailed biostratigraphical framework for the late Pliensbachian-early Toarcian of central Italy. This scheme demonstrates that the integration of phytoplankton data may represent an important parachronology to the ammonite zonation, which provides the orthochronology of the Jurassic. The integration of different phytoplankton groups ensures more precise biochronology and the ability to date sediments even when lithologies unfavourable to the preserva- tion of one fossil group are present.

The success of this biostratigraphical approach derives from the different evolutionary history of the two phytoplankton groups. The slight diachroneity between the early Jurassic radiation of nannoplankton and dinoflagellate cysts is linked to the interplay of phytoplankton life cycles and global events. The calcareous nannoplankton exhibit a maximum in diversification at the Pliensbachian-Toarcian transition, probably produced by the inception of early Toarcian sea level rise. It is coincident with the negative excursion of the $\delta^{13} \mathrm{C}$ curve of Jenkyns \& Clayton (1997), about $1 \mathrm{Ma}$ before the oceanic anoxic event (Fig. 3) and the positive excursion of the $\delta^{13} \mathrm{C}$ curve of Jenkyns \& Clayton (1997). The early Jurassic sea level rise produced high diversification rates within dinoflagellate community, earlier than for nannoplankton, in the early Pliensbachian (Mattioli \& Bucefalo Palliani, 1995). Concomitant with the stressed conditions, related to the inception of the global anoxic event, dinoflagellates exhibit high turnover, while nannoplankton had a low diversification period. After the global anoxic event a second diversification pulse of nannoplankton occurred, which saw the appearance of the important Discorhabdus and Watznaueria genera. With regard to dinoflagellates, the following diversification pulse is in the $H$. bifrons Zone, when the recovery of the oxygenated conditions at the sea bottom produced an increase of the available habitats.

The differences between the evolutionary trends of the two phytoplanktonic groups can be ascribed to their life cycles. Nannoplankton are a meroplanktonic group, exclusively dependent on the water column conditions and therefore their speciation events are mainly linked to a transgressive trend and to the $\mathrm{CO}_{2}$ balance in the atmosphere/oceans system (Bartolini et al., 1996). However, cyst producing dinoflagellates have a benthonic stage in their life cycle and are, therefore, influenced by the sea bottom conditions. Widespread anoxic conditions during a sea level rise produce a decrease in the available niches and favoured extinction events. The regressions may be related to dinoflagellate speciations if they are concomitant with the oxygenation of the sea bottom.

The high number of phytoplankton events recorded in central Italy makes possible a detailed correlation of the studied sections. In Fig. 2 the correlation lines based on integrated calcareous nannofossil and dinoflagellate cyst biostratigraphies are displayed. They reveal a variable accumulation rate among the different profiles and along the same succession. The accumulation rate is relatively high in the northern sector of the Umbria-Marche basin (Colle d'Orlando and Monte Serrone) with respect to the southern one (Somma and Fonte Cerro). The Pozzale section seems to show the most constant accumulation rate. A minimum thickness between the FO of $C$. superbus and $L$. velatus has been recorded in the expanded Monte Serrone succession. All the events inbetween have not been recorded. This may be the effect of a variation in the accommodation space, which prevented a large accumulation, or the effect of synsedimentary gravitational processes.

The biostratigraphical framework obtained in the present work yielded a detail greater than that provided by ammonites and generally independent from the sedimentary facies. Moreover, the integration of phytoplankton events may give preliminary information about the palaeoenvironmental evolu- 
tion of a sedimentary basin, in spite of the scarcity of sedimentary structures and the apparent uniformity of vertical succession of lithotypes.

\section{ACKNOWLEDGEMENTS}

We warmly thank Drs Simonetta Cirilli (University of Perugia) and James Riding (British Geological Survey) for helpful comments and stimulating discussion. The valuable comments and remarks of James Riding and an anonymous reviewer have greatly improved this manuscript. This research is supported by the research funds to Dr S. Cirilli and Prof G. Parisi (University of Perugia) and by a Training and Mobility of Researchers European Commission research grant (contract number ERBFMBICT960661).

\section{Appendix A}

\section{Species index}

Calcareous nannofossils

Biscutum dubium (Noël 1965) Grün in Grün et al. 1974

Biscutum finchii (Crux 1984) Bown 1987

Biscutum grande Bown 1987

Biscutum novum (Goy 1979) Bown 1987

Bussonius prinsii (Noel 1973) Goy 1979

Bussonius leufuensis Bown \& Kielbowicz 1987 in Bown 1987

Calyculus sp. indet.

Carinolithus poulnabronei Mattioli 1996

Carinolithus superbus (Deflandre 1954) Prins in Grün et al. 1974

Crepidolithus cavus Rood, Hay \& Barnard 1973

Crepidolithus crassus (Deflandre 1954) Noël 1965

Crepidolithus granulatus Bown 1987

Discorhabdus criotus Bown 1987

Discorhabdus ignotus (Gorka 1957) Perch-Nielsen 1968

Discorhabdus striatus Moshkovitz \& Ehrlich 1976

Lotharingius barozii Noël 1973

Lotharingius crucicentralis (Medd 1971) Grün \& Zweili 1980

Lotharingius frodoi Mattioli 1996

Lotharingius hauffii Grün \& Zweili in Grün et al. 1974

Lotharingius sigillatus (Stradner 1961) Prins in Grün et al. 1974

Lotharingius umbriensis Mattioli 1996

Lotharingius velatus Bown \& Cooper 1989

Mitrolithus elegans Deflandre 1954

Mitrolithus jansae (Wiegand 1984) Bown \& Young in Young et al. 1986

Mitrolithus lenticularis Bown 1987

Parhabdolithus liasicus Deflandre 1952

Schizosphaerella sp. indet.

Similiscutum cruciulum De Kaenel \& Bergen 1993

Sollasites lowei (Bukry, 1969) Rood et al. 1971

Tubirhabdus patulus Rood et al. 1973

Watznaueria colacicchii Mattioli 1996

Watznaueria sp.1 Cobianchi et al. 1992

Dinoflagellate cysts

Jansonia sp.

Luehndea spinosa Morgenroth 1970

Mencodinium semitabulatum Morgenroth 1970 emend. Below 1987

Mendicodinium brunneum Bucefalo Palliani et al. 1997
Mendicodinium microscabratum Bucefalo Palliani et al. 1997

Mendicodinium spinosum subsp. perforatum Bucefalo Palliani et al. 1997

Mendicodinium spinosum subsp. spinosum Bucefalo Palliani et al. 1997

Mendicodinium umbriense Bucefalo Palliani et al. 1997

Ovalicysta cf. hiata Bjaerke 1980

Susadinium scrofoides Dörhöfer \& Davies 1980 emend. Below 1987

Umbriadinium mediterraneense Bucefalo Palliani \& Riding 1997 Valvaeodinium hirsutum Bucefalo Palliani \& Riding 1997

Valvaeodinium koessenium Morbey 1975 comb. nov. Below 1987 Valvaeodinium punctatum Wille \& Gocht 1979 emend. Below 1987

Valvaeodinium cf. perpunctatum Wille \& Gocht 1979 emend. Below 1987

Valvaeodinium stipulatum Wille \& Gocht 1979 emend. Below 1987

\section{Appendix B}

Stratigraphical distribution of calcareous nannofossils in central Italy. Relative abundances have been calculated after a count of 250-300 specimens per smear slide. The number of views in which the standard quantity of specimens has been reached is taken into account for the total abundance evaluation.

\begin{tabular}{|l|}
\hline \multicolumn{1}{|c|}{ Total abundance per field of view } \\
\hline $\mathbf{V A}=$ very abundant, more than 15 specimens \\
\hline $\mathbf{A}=$ abundant, 10 to 15 specimens \\
\hline $\mathbf{C}=$ common, 1 to 10 specimens \\
\hline $\mathbf{F}=$ few, 0.1 to 1 specimens \\
\hline $\mathbf{R}=$ rare, less than 0.1 specimens \\
\hline $\mathbf{B}=$ barren \\
\hline \\
\hline $\mathbf{V A}=$ very abundant, more than 5 specimens in one field of view \\
\hline $\mathbf{A}=$ abundant, 1 to 5 specimens in one field of view \\
\hline $\mathbf{C}=$ common, 1 specimen in 1 to 10 fields of view \\
\hline $\mathbf{F}=$ few, 1 specimen in $10-30$ fields of view \\
\hline $\mathbf{R}=$ rare, 1 specimen in more than 30 fields of view \\
\hline $\mathbf{X}=1$ specimen in the smear slide \\
\hline $\mathbf{P}=$ questionable presence \\
\hline \\
\hline $\mathbf{G}=$ Preservation \\
\hline $\mathbf{M}=$ moxd, withoul dissolution nor overgrowth effects \\
\hline $\mathbf{P}=$ poor, clear traces of dissolution/overgrowth \\
\hline $\mathbf{V P}=$ diagenesis makes difficult the specific determination \\
\hline $\mathbf{L}=$ Species richness \\
\hline $\mathbf{M}=$ medium, 5 to 15 species in the assemblage \\
\hline
\end{tabular}

Fig. B1. Parameters used for the total and relative abundance evaluation; preservation and species richness classes. 


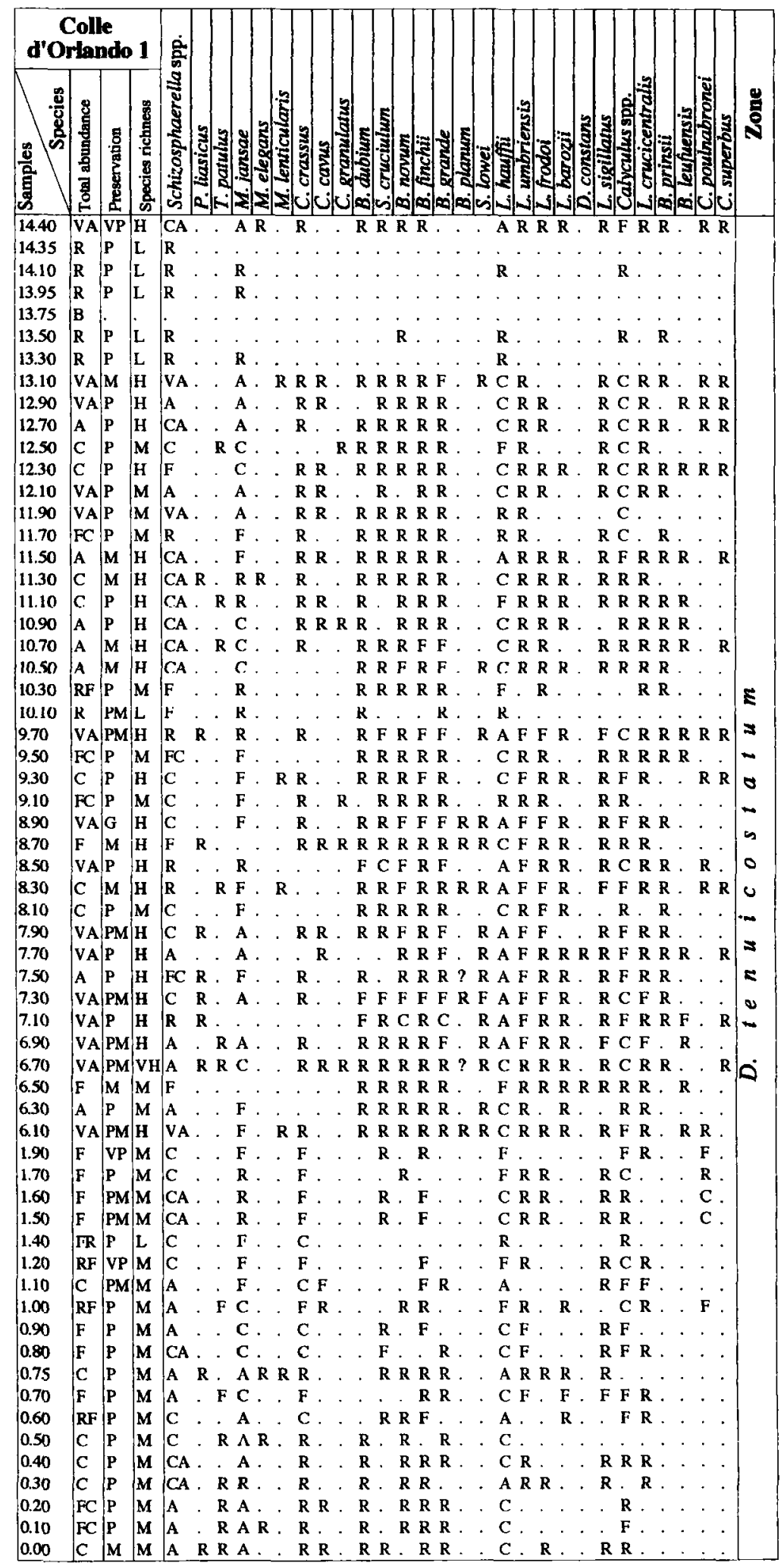

Fig. B2. Calcareous nannofossil distribution in the Colle d'Orlando section, lower part. 


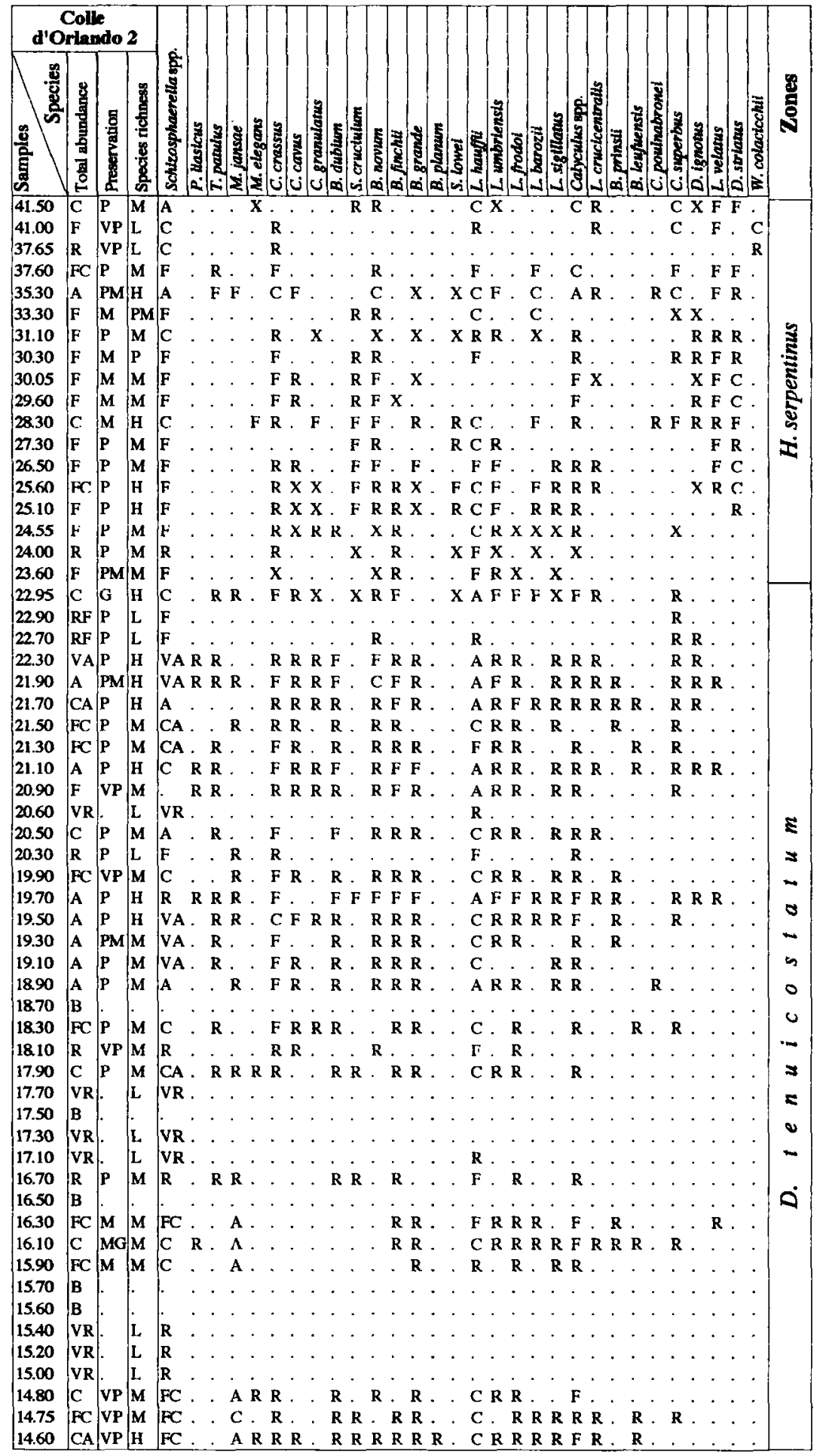

Fig. B3. Calcareous nannofossil distribution in the Colle d'Orlando section, upper part. 


\begin{tabular}{|l|l|l|l|l|l|l|l|l|l|l|l|l|}
\hline \multicolumn{2}{|l|}{ Monte Serrone } & \\
\hline
\end{tabular}

Fig. B4. Calcareous nannofossil distribution in the Monte Serrone section.

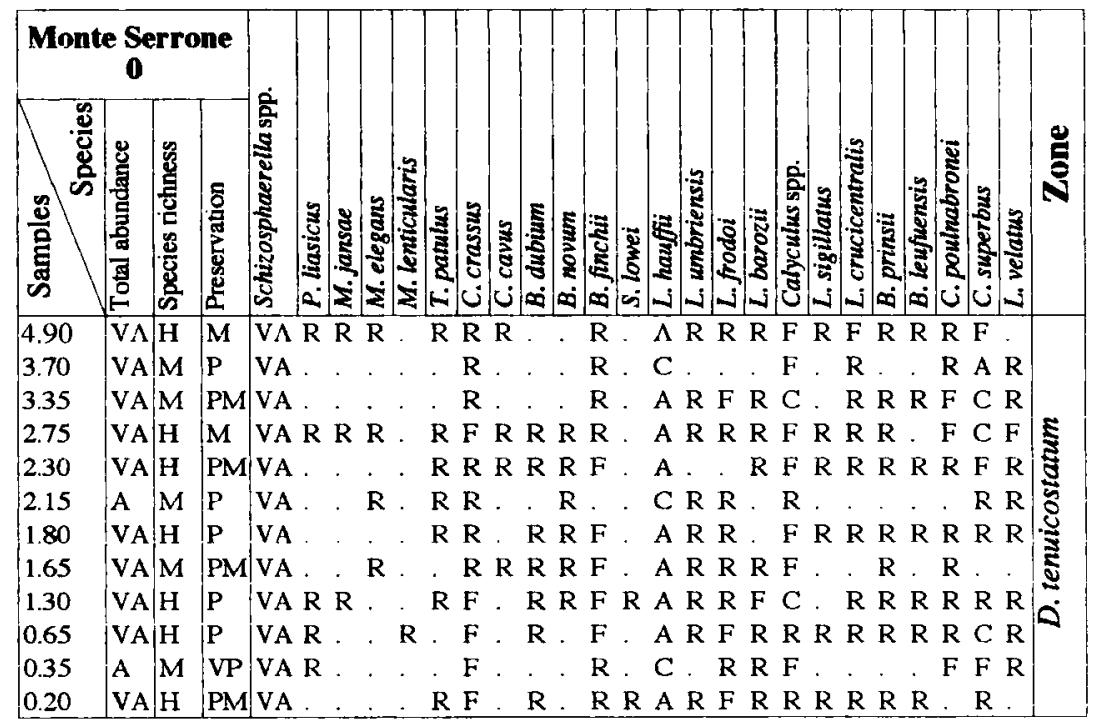

Fig. B5. Calcareous nannofossil distribution in the Monte Serrone section, southern sector. 


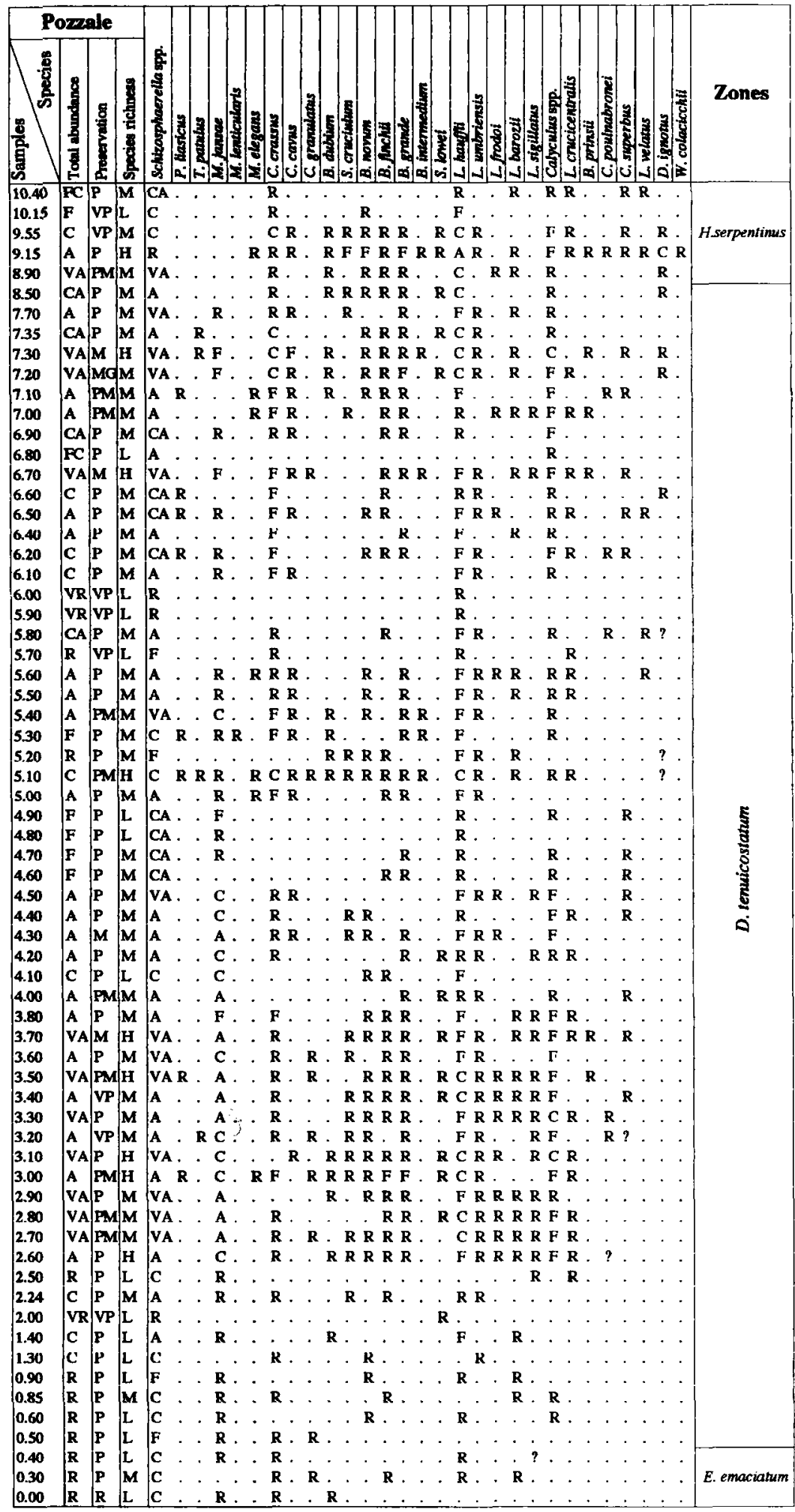

Fig. B6. Calcareous nannofossil distribution in the Pozzale section. 


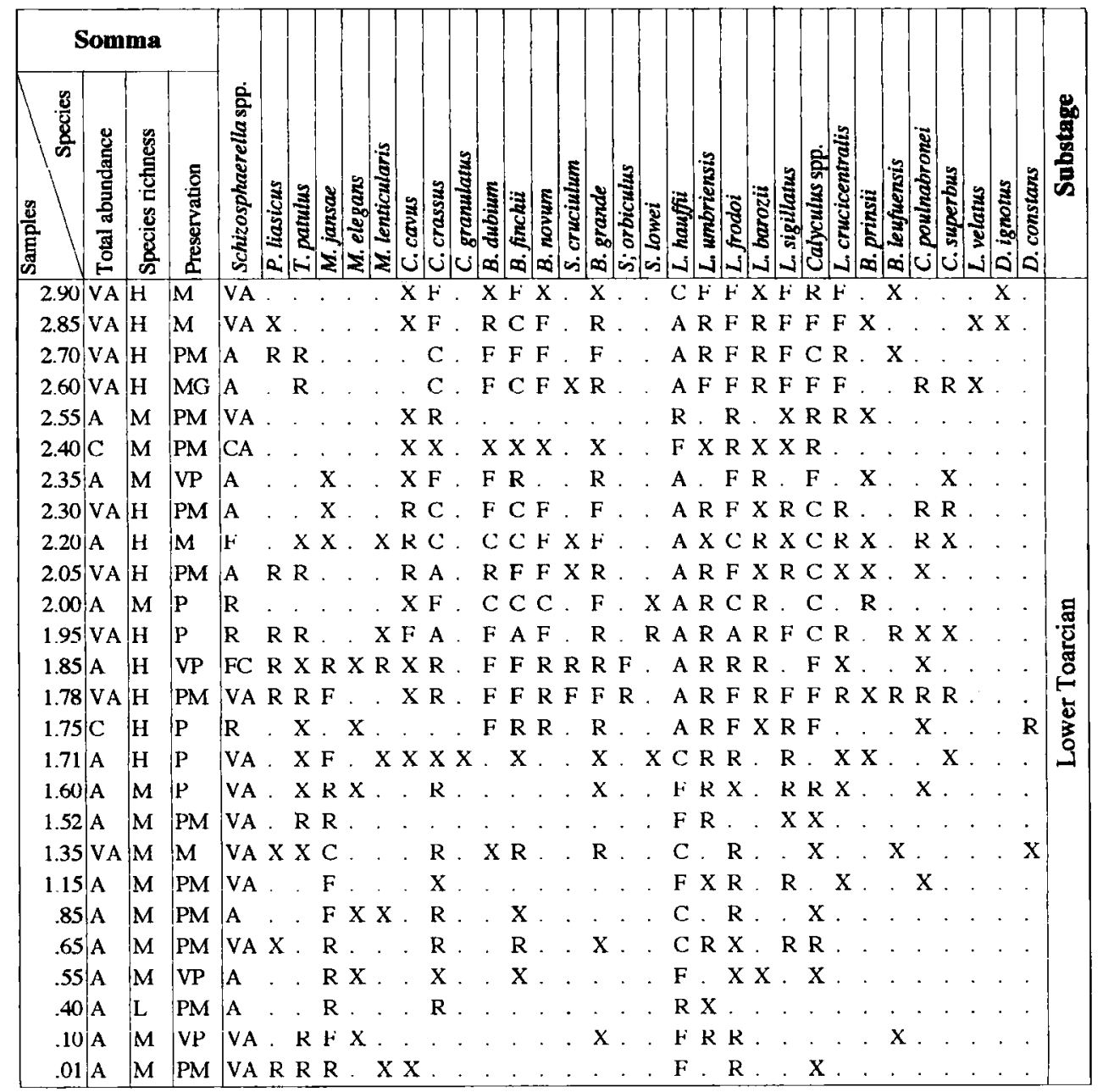

Fig. B7. Calcareous nannofossil distribution in the Somma section. 


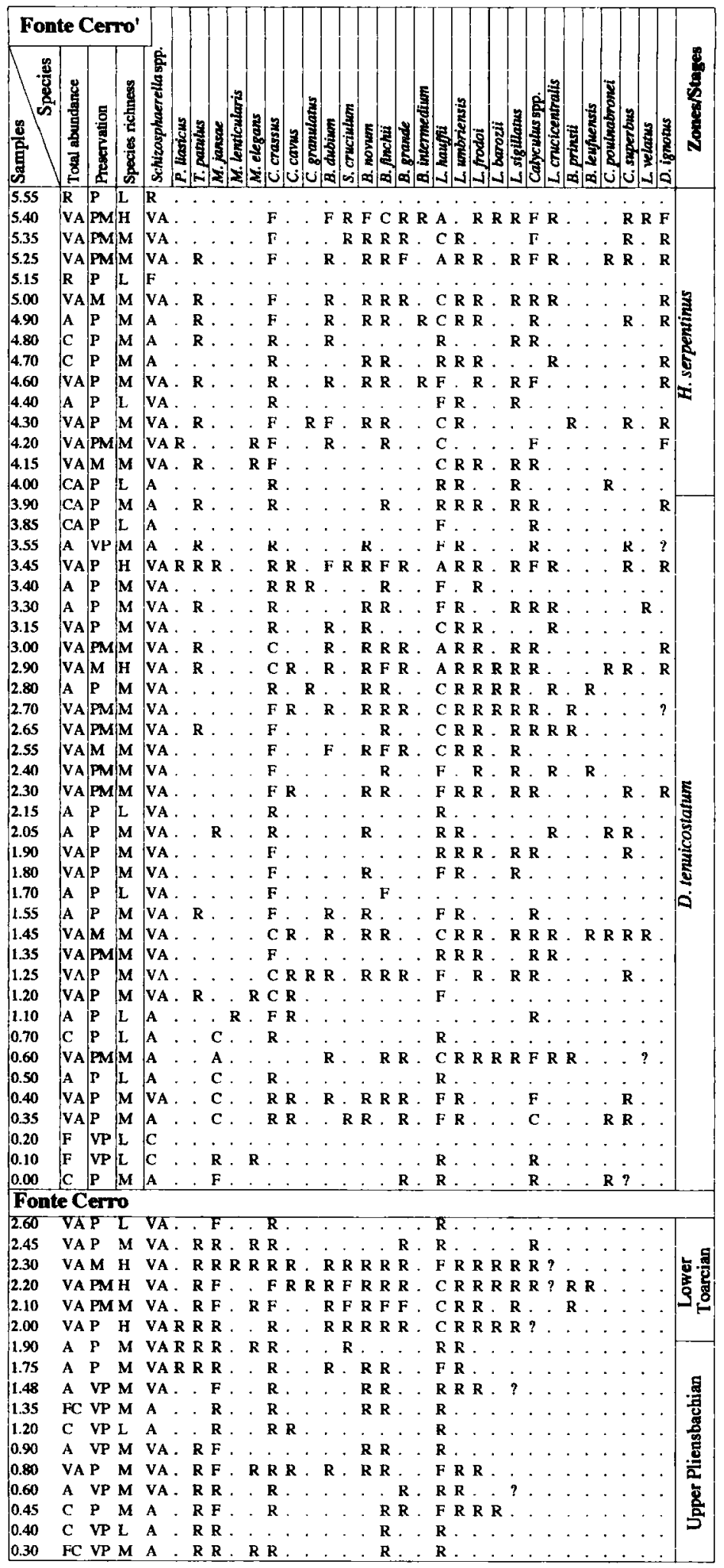

Fig. B8. Calcareous nannofossil distribution in the Fonte Cerro section. 
Appendix C

Semi-quantitative distribution of dinoflagellate cysts in the Lower Jurassic of central Italy. The abundances have been estimated by averaging the number of dinoflagellate cysts counted for each species in three slides. A species was classified rare (R) if it averaged between 0 and 5 , common (C) if it averaged between 5 and 10 , frequent $(F)$ if it averaged between $10-20$ and abundant if it averaged more than 20 dinoflagellate cysts.

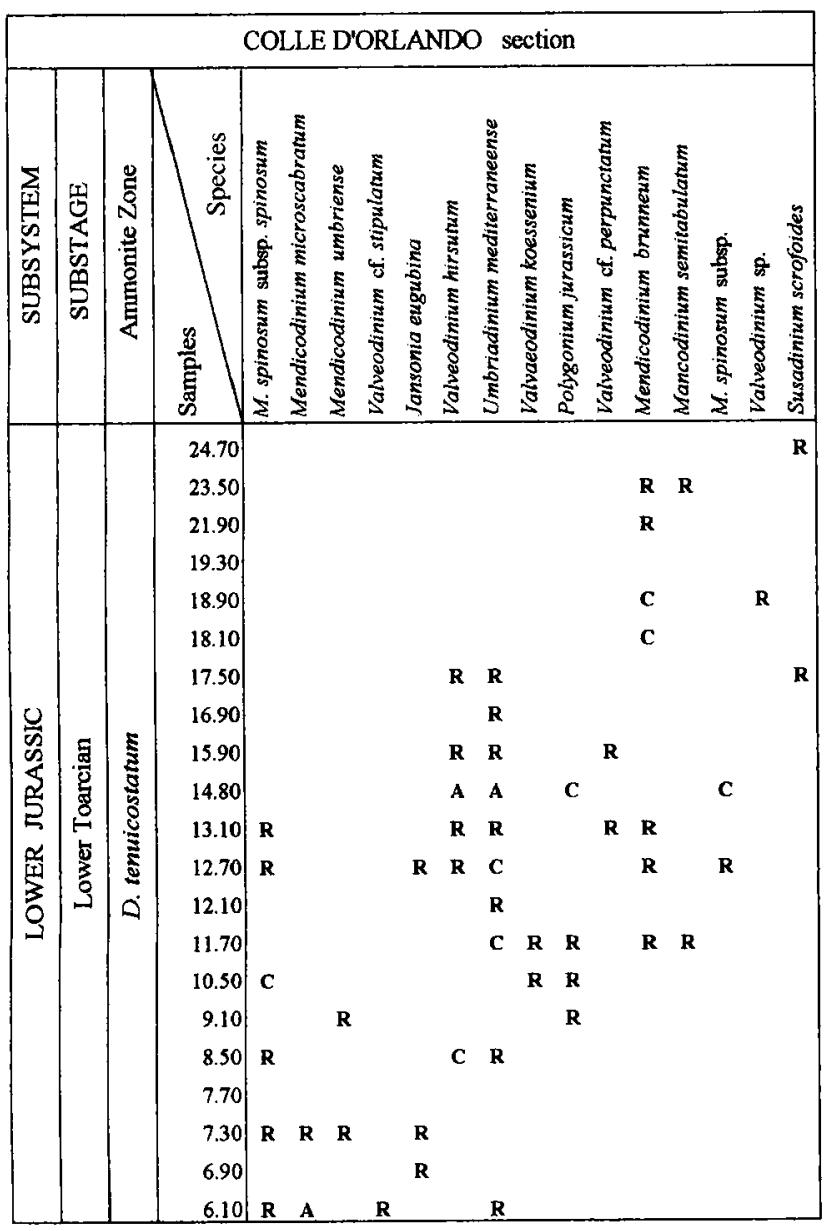

Fig. C1. Dinoflagellate cyst distribution in the Colle d'Orlando section.

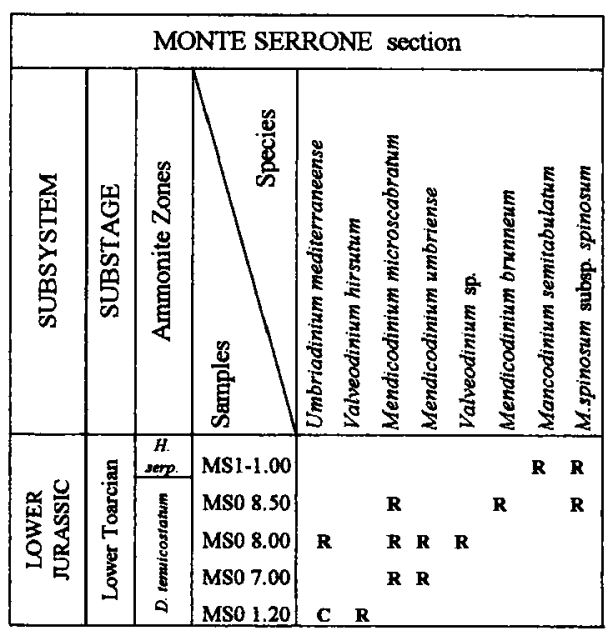

Fig. C2. Dinoflagellate cyst distribution in the Monte Serrone section.

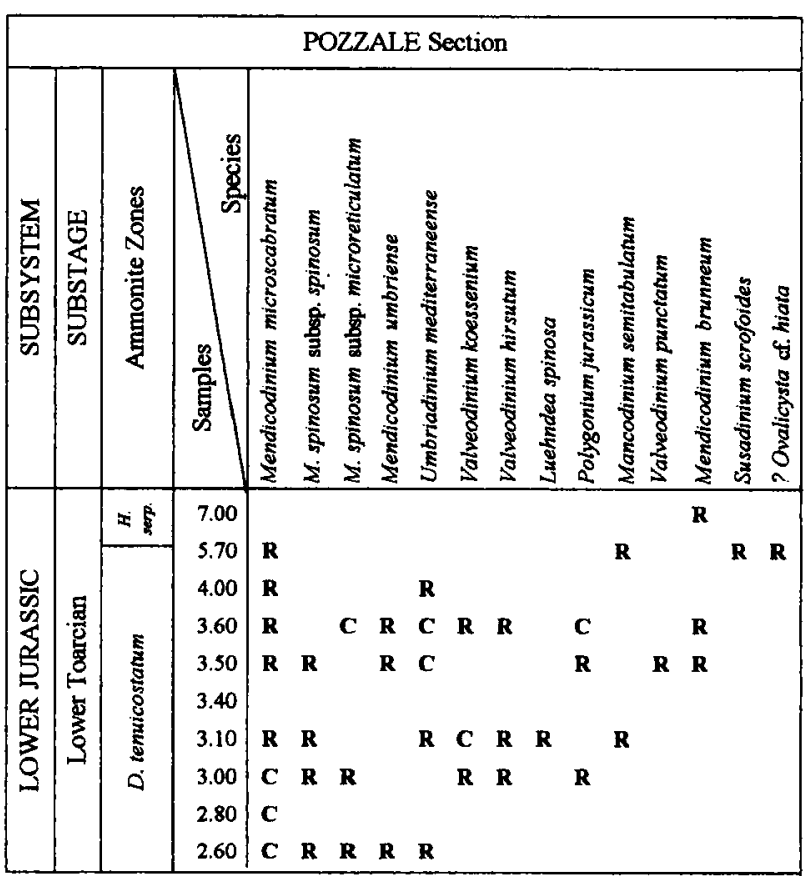

Fig. C3. Dinoflagellate cyst distribution in the Pozzale section. 


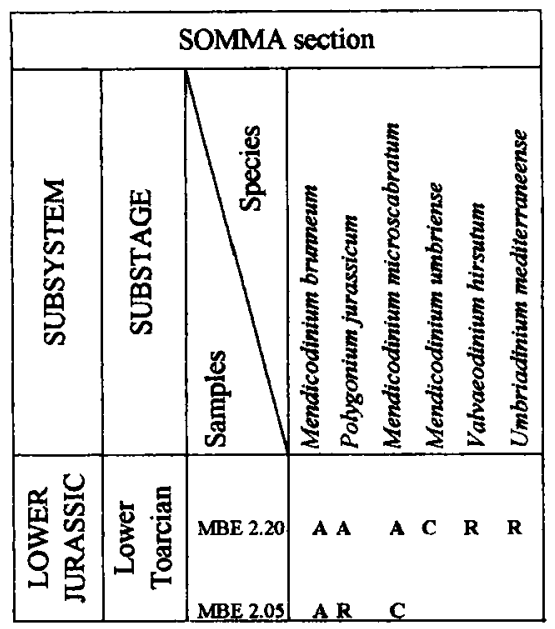

Fig. C4. Dinoflagellate cyst distribution in the Somma section.

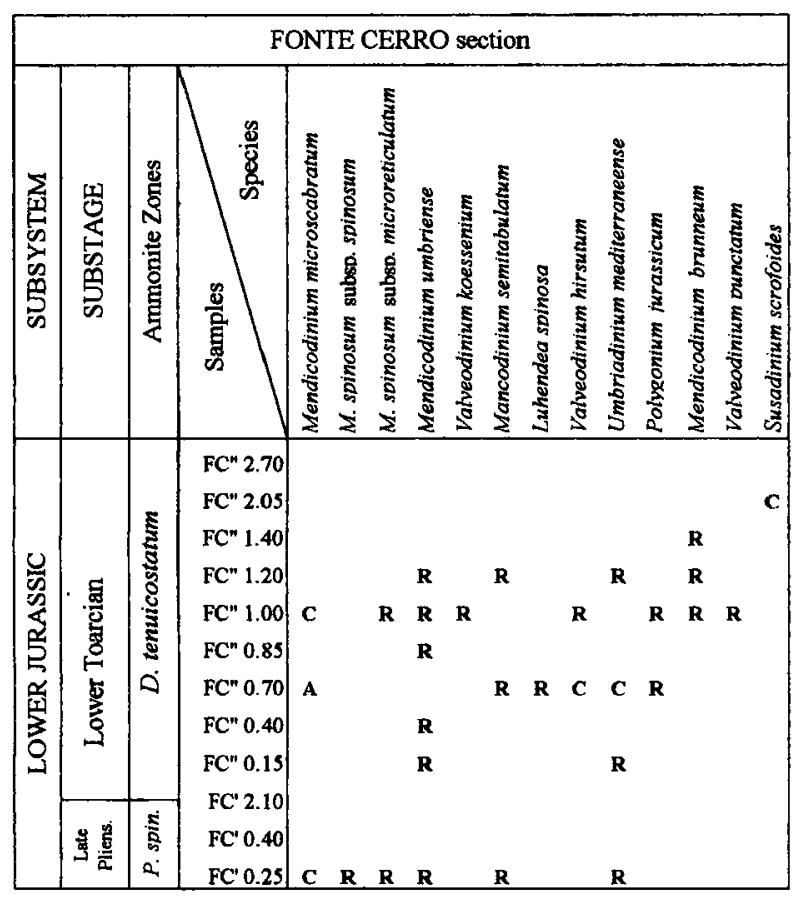

Fig. C5. Dinoflagellate cyst distribution in the Fonte Cerro section.

\section{Manuscript received November 1997 Manuscript accepted September 1998}

\section{REFERENCES}

Arkell, W. J. 1956. Jurassic Geology of the World. Oliver and Boyd, 806 pp.

Baldanza, A., Bucefalo Palliani, R. \& Mattioli, E. 1995. Calcareous nannofossils and dinoflagellate cysts from the Late Liassic of Hungary and comparison with Central Italy assemblages. Paleopelagos, 5: 161174.

Bartolini, A., Baumgartner, P. O., Erba, E. \& Mattioli, E. 1996.
Plankton response to $\mathrm{CO}_{2}$ budget change during the middle Jurassic (Aalenian-Bajocian). SEPM/IAS Research Conference, Carbonate and Global Change: an Interdisciplinary Approach, Abstracts, 19.

Bown, P. R. 1987. Taxonomy, evolution and biostratigraphy of Late Triassic-Early Jurassic calcareous nannofossils. Palaeontological Association, Special Papers in Palaeontology, 38.

Bown, P. R. 1996 (with contributions from the International Nannoplankton Association, Jurassic Working Group-A. Baldanza, J. Bergen, M. Cobianchi, K. Cooper, E. Erba, S. Gardin, E. de Kaenel, F. Lozar, E. Mattioli, S. Monechi, C. Pirini Radrizzani, V. Reale \& P. Roth). Recent advances in Jurassic calcareous nannofossil research. GeoResearch Forum, 1-2: 55-66.

Bown, P. R., Cooper, M. K. E. \& Lord, A. 1988. A calcareous nannofossil biozonation scheme for the early to mid Mesozoic. Newsletters in Stratigraphy, 20(2): 91-114.

Bucefalo Palliani, R. 1996. Facies organiche nel Giurassico inferiore del dominio Tetideo: sedimentologia organica e biostratigrafia a cisti di dinoflagellati. Ph.D. Thesis, University of Perugia, Italy, $168 \mathrm{pp}$.

Bucefalo Palliani, R. \& Cirilli, S. 1993. Palaeonvironmental influences on the composition and preservation of the organic matter: preliminary results from the Pozzale section (Early Toarcian, Central Apennines, Italy). Paleopelagos, 3: 129-144.

Bucefalo Palliani, R. \& Mattioli, E. 1994. Enrichment in organic matter within the Early Toarcian Marne di Monte Serrone Formation: a synchronous event in the Umbria-Marche Basin (central Italy). Paleopelagos, 4: 129-140.

Bucefalo Palliani, R. \& Mattioli, E. 1995. Ecology of dinoflagellate cysts and calcareous nannofossils from bituminous facies of the Early Toarcian, central Italy. Europal, 8: 6062 .

Bucefalo Palliani, R. \& Riding, J. B. 1997 a. Umbriadinium mediterraneense gen. et sp. nov. and Valvaeodinium hirsutum sp. nov.: two dinoflagellate cysts from the Lower Jurassic of the Tethyan Realm. Palynology, 21: 197-206.

Bucefalo Palliani, R. \& Riding, J. B. 1997b. Lower Toarcian palynostratigraphy of Pozzale, central Italy. Palynology, 21: 91-103.

Bucefalo Palliani, R \& Riding, J. B. 1998. The influence of palaeoenvironmental change on dinoflagellate cyst distribution: an example from the Lower and Middle Jurassic of Quercy, southwest France. Bull. Centres Rech. Explor.-Prod. Elf Aquitaine. 21(1): 107123.

Bucefalo Palliani, R \& Riding, J. B. in press. Early Jurassic (Pliensbachian-Toarcian) dinoflagellate migrations and cyst palaeoecology in the Boreal and Tethyan realms. Micropaleontology.

Bucefalo Palliani, R., Riding, J. B \& Torricelli, S. 1996. Polygonium jurassicum sp. nov. a polygonomorph acritarchs from Early Toarcian of Tethyan Realm. Palynology, 20: 157-161.

Bucefalo Palliani, R., Riding, J. B. \& Torricelli, S. 1997. The dinoflagellate cyst Mendicodinium Morgenroth, 1970 emend. nov. from the Lower Toarcian (Jurassic) of Central Italy. Review of Paleobotany and Palynology, 96: 99-111.

Bucefalo Palliani, R., Cirilli, S. \& Mattioli, E. 1998. Phytoplanktonic responses and geochemical evidences of the Early Toarcian relative sea level rise in the Umbria-Marche basin (Central Italy). Palaeogeography, Palaeoclimatology, Palaeoecology. 142: 33-50

Colacicchi, R., Nocchi, M., Parisi, G., Monaco, P., Baldanza, A., Cresta, S. \& Pallini, G. 1989. Palaeoenvironmental analysis from Lias to Malm (Corniola to Maiolica Formations) in the Umbro-Marchean basin, Central Italy (preliminary report). 2nd International Symposium on Jurassic Stratigraphy, 2: 717-728.

Cresta, S., Cecca, F., Santantonio, M., Pallini, G., Baldanza, A., Colacicchi, R., Monaco, P., Nocchi, M., Parisi, G. \& Venturi, F. 1989. Stratigraphic correlations in the Jurassic of the Umbria-Marche Apennines (Central Italy). 2nd International Symposium on Jurassic Stratigraphy, 2: 729-744.

Crux, J. A. 1984. Biostratigraphy of early Jurassic calcareous nannofossils from southwest Germany. Neues $\mathrm{Jb}$. Geol. Palaont., 169: $160-186$.

Gradstein, F. M., Agterberg, F. P., Ogg, J. G., Hardenbol, J., van Veen, P., Thierry, J. \& Huang, Z. 1994. A Mesozoic time scale. Journal of Geophysical Research, 99: 24.051-24.074.

Hallam, A. 1987. Mesozoic marine organic-rich shales. In Brooks, J. \& Fleet, A. J. (Eds), Marine Petroleum Source Rocks, Geological 
Society, London, Special Publications, 26: 251-261.

Hallock, P. 1987. Fluctuations in the trophic resource continuum: a factor in global diversity cycles? Palaeoceanography, 2: 457-471.

Jenkyns, H. C. 1985. The Early Toarcian and Cenomanian-Turonian anoxic events in Europe: comparisons and contrasts. Geologische Rundschau, 74: 505-518.

Jenkyns, H. C. \& Clayton, C. J. 1997. Lower Jurassic epicontinental carbonates and mudstones from England and Wales: chemostratigraphic signals and the early Toarcian anoxic event. Sedimentology, 44: 687-706.

Mattioli, E. 1995. Late Liassic calcareous nannofossils from the Pozzale section (Martani Mts, Central Italy): a quantitative approach to evaluate productivity and diagenesis. Acta Congreso Nanoplancton Proceedings of the 5th INA Conference, Salamanca (Spain), Flores, J. A. \& Sierro, F. J. (Eds), 83-103.

Mattioli, E. 1996. New Calcareous Nannofossil species from the Early Jurassic. Rivista Italiana di Paleontologia e Stratigrafia, 102: 397-412.

Mattioli, E. \& Bucefalo Palliani, R. 1995. Phytoplanktonic evolution and extinctions related to the Late Liassic anoxic event. Europal, 8: 69-70.

Mattioli, E. \& Erba, E. in press. Biostratigraphical synthesis of Jurassic calcareous nannofossils. Rivista Italiana di Paleontologia e Stratigrafia.

Morbey, S. J. 1975. The palynostratigraphy of the Rhaetian Stage, Upper Triassic in the Kendelbachgraben, Austria. Palaeontographica, 153: $1-75$.

Morgenroth, P. 1970. Dinoflagellate cysts from the Lias Delta of Luhnde/Germany. Neues Jarbuche für Geologie und Paläontologie, 163: 9-13.

Nini, C., Bucefalo Palliani, R., Mattioli, E., Morettini, E., Monaco, P. \& Nocchi, M. 1995. Organic rich facies: some example from Mesozoic and Cenozoic of the Northern Apennines. III EPA Workshop: Black Shales Models, Abstracts, 53-54.

Pialli, G. 1969. Un episodio marnoso del Lias superiore nel bacino
Umbro-Marchigiano: le Marne di Monte Serrone. Bollettino Società Naturalisti, 78: 345-359.

Reale, V., Baldanza, A., Monechi, S. \& Mattioli, E. 1992. Calcareous nannofossil biostratigraphic events from the Early-Middle Jurassic sequences of the Umbria-Marche area (central Italy). Memorie Scienze Geologiche di Padova, XLIII: 41-75.

Riding, J. B. 1984. A palynological investigation of Toarcian and early Aalenian strata from the Blea Wyke area, Revenscar, North Yorkshire. Proceedings of the Yorkshire Geological Society, 45: 109122.

Riding, J. B. 1987. Dinoflagellate cyst stratigraphy of the Nettleton Bottom Borehole (Jurassic: Hettangian to Kimmeridgian), Lincolnshire, England. Proceedings of the Yorkshire Geological Society, 46: 231-266.

Riding, J. B. \& Thomas, J. E. 1992. Dinoflagellate cysts of the Jurassic System. In: A. J. Powell (Ed.), A Sratigraphic Index of Dinoflagellate Cysts. British Micropalaeontological Society Publication Series, Chapman \& Hall, London, 7-97.

Roth, P. H. 1986. Mesozoic calcareous nannofossil evolution: relation to paleoceanographic events. Palaeoceanography, 2: 601-611.

Tyson, R. V. 1987. The genesis and palynofacies characteristics of marine petroleum source rocks. In Brooks, J. \& Fleet, A. J. (Eds), Marine Petroleum Source Rocks, Geological Society, London Special Publications, 26: 47-67.

Wille, W. \& Gocht, H. 1979. Dinoflagellaten aus dem Lias Südwestdeutschlands. Neues Jarbuche für Geologie und Paläontologie, 158: 221-258.

Wood, G. D., Gabriel, A. M. \& Lawson, J. C. 1996. Palynological techniques - processing and microscopy. In Jansonius, J. \& Mcgregor, D. C. (Eds) Palynology: Principles and Applications. American Association Stratigraphical Palynologist Foundation, 1: 29-50

Woollam, R. \& Riding, J. B. 1983. Dinoflagellate cyst zonation of the English Jurassic. Institute of Geological Sciences Report, 83/2: 1-42. 